\title{
EARLY PROTEROZOIC STRATIGRAPHY OF THE SALAHMI-PYHÄNTÄ AREA, CENTRAL FINLAND, WITH AN EMPHASIS ON APPLYING THE PRINCIPLES OF LITHODEMIC STRATIGRAPHY TO A COMPLEXLY DEFORMED AND METAMORPHOSED BEDROCK
}

\author{
K. LAAJOKI and J. LUUKAS
}

\begin{abstract}
LAAJOKI, K. and LUUKAS, J., 1988: Early Proterozoic stratigraphy of the Salahmi-Pyhäntä area, central Finland, with an emphasis on applying the principles of lithodemic stratigraphy to a complexly deformed and metamorphosed bedrock. Bull. Geol. Soc. Finland 60, Part 2, 79-106.

The medium-highly metamorphozed and intensely deformed early Proterozoic supracrustal rocks of the study area, located at the boundary zone between the Karelian and Svecofennian zones in central Finland, are classified following the recommendations of the North American Stratigraphic Code into 16 lithostratigraphic and lithodemic units.

The lithostratigraphic procedures can be applied only to the southeastern corner of the area where the late Archaean basement complex is rimmed by less than 100 metres thin fluvial metapsammite formations locally underlain by a thin palaeosol of sericite and chloritoid schists. These formations, which are correlated with the Kainuu tectofacies, are overlain by at least $1 \mathrm{~km}$ thick sequence of turbiditic metapsephites and metapsammites of the Haajainen and Rotimojoki formations of the western Kaleva tectofacies.

The major central part of the area is cored by two gneiss complexes, earlier considered to be the Archaean basement, but now classified mostly as lithodemic derivatives of the Kaleva tectofacies. These complexes are mantled by gneisses and schists which represent western, more metamorphosed distal equivalents of the Haajainen and Rotimojoki formations. The western margin of the area is composed of gneisses and schists part of which show Svecofennian affinities.

Excluding the Archaean basement, the area is intruded and migmatized by Svecokarelidic intrusive rocks.
\end{abstract}

Key words: Stratigraphy, metasedimentary rocks, gneisses, schists, Proterozoic, Vieremä, Kiuruvesi, Pyhäntä, Finland.

K. Laajoki and J. Luukas: Department of Geology, University of Oulu, Linnanmaa, SF-90570 Oulu, Finland.

\section{Introduction}

One of the greatest problems of the early Proterozoic geology of Finland is the relationship between the Karelian and Svecofennian supracrustal rocks and the location of their border zone. Understanding this relationship is of utmost impor- tance in developing models for the early Proterozoic evolution of the Fennoscandian Shield in central Finland (see Gaál and Gorbatschev 1987 and references in it).

In 1985, the Department of Geology of the University of Oulu began investigations in the Salahmi-Näläntö area which occupies the zone 


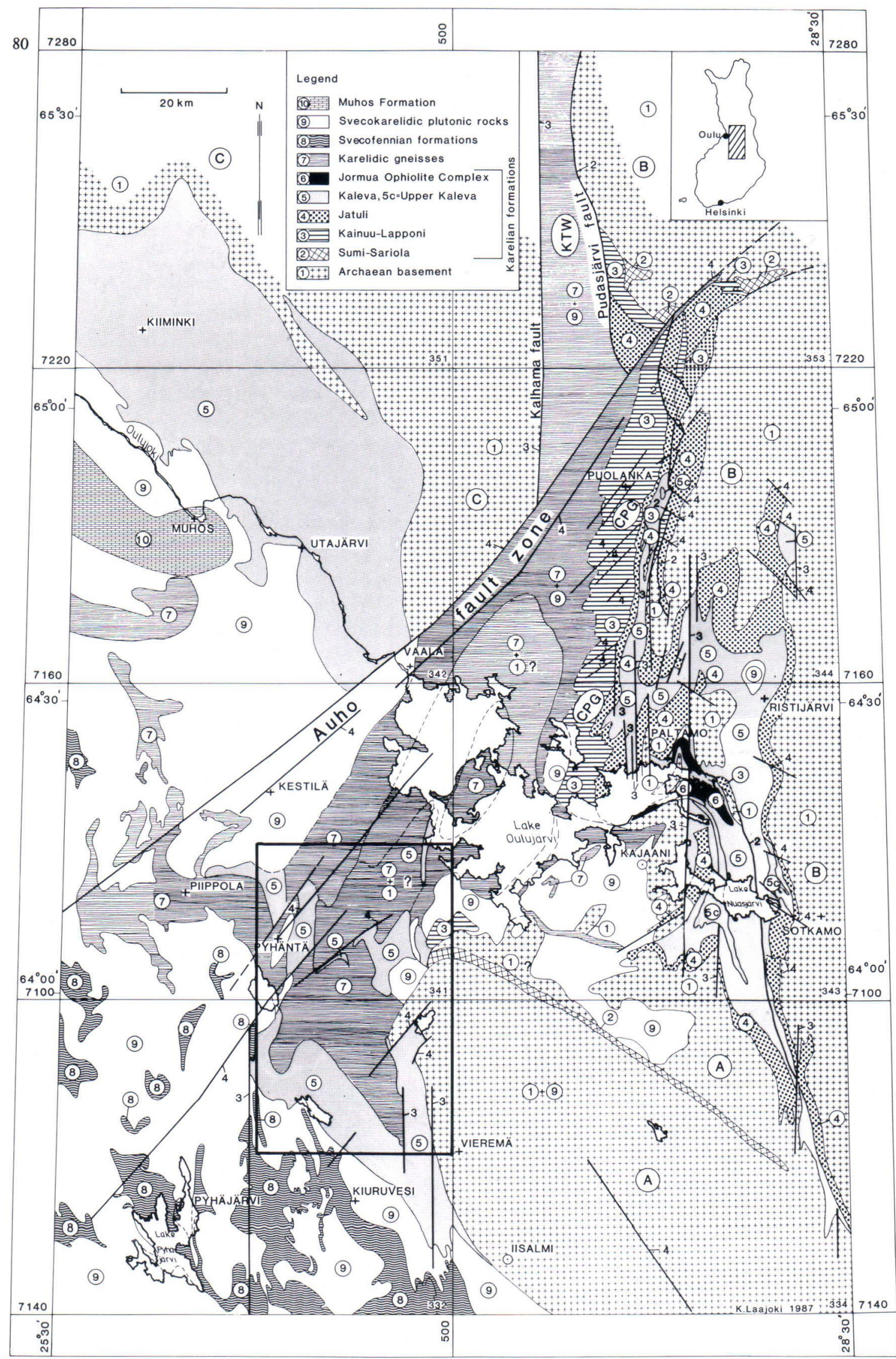


between the Kainuu Schist Belt, a representative of the Karelian schist areas, and the Svecofennian rocks of central Finland (Fig. 1). The study area covers map sheets 3324 and 3413 totalling $2400 \mathrm{~km}^{2}$ in areal. It comprises the major northern part of Savolahti's (1965) Vieremä-Kiuruvesi belt, and the granitic gneisses between Pyhäntä and Vuolijoki, which have generally been included in the Archaean basement (e.g. Simonen 1980a).

The results presented here are based on J. Luukas' (1987) detailed field work in the surroundings of Itämäki and on our more regional work carried out in 1986 and 1987. Detailed sedimentological and stratigraphic studies of the Salahmi Schist Belt have been published elsewhere (Korkiakoski and Laajoki 1988) and are only reviewed in this paper. Prelimary structural and metamorphic geological results are given by Laajoki et al. (1988).

The main aim is to classify formally the early Proterozoic supracrustal rocks of the study area into stratigraphic units. It will also be demonstrated that the schists and gneisses of Salahmi and Näläntöjärvi can be mapped in the form of their lithodemic counterparts northwestwards to Pyhäntä and that the bulk of the granitic gneisses of Pyhäntä and Vuolijoki represent early Proterozoic paragneisses rather than the Archaean granitoid basement. The space limit does not allow detailed descriptions of individual units to be given but some of them have already been described by Korkiakoski and Laajoki (1988) and Luukas (1987).

\section{Stratigraphic procedures}

The bedrock of the study area consists mainly of multiply deformed gneissic rocks metamor- phosed to upper amphibolite facies, migmatized and intruded in abundance by granitic and other intrusive rocks. Only a fraction of them show primary sedimentary features, a number are paragneisses whereas other are gneisses of unsure origin. Because of this their stratigraphic classification is not easy and we have to face the disputed question of how igneous and metamorphic rock bodies should be classified in terms of stratigrapy. The North American Commission on Stratigraphic Nomenclature (1983) (hereafter NACSN) makes a distinction between lithostratigraphic and lithodemic units, of which the former include metasedimentary and metavolcanic strata, mostly stratified, which generally obey the Law of Superposition and consequently, their stratigraphic positions are known, whereas the latter include intrusive, highly deformed, and/or highly metamorphosed rocks which generally do not conform to the Law of Superpositon. The International Subcommission on Stratigraphic Classification (ISSC) (1987), however, recommends that all rock bodies which are defined and recognized on the basis of their diagnostic lithology should be considered as lithostratigraphic units.

The authors feel that if metamorphic and igneous rocks are included in the stratigraphy in the sense proposed by the ISSC (1987) the terms stratigraphy and lithostratigraphy deviate so much from their original meanings and even from the definitions of the International Stratigraphic Guide (Hedberg 1976) that traditional stratigraphy (the study of strata or stratified rocks) would, for clarity's sake, require a term of its own, e.g. "stratostratigraphy». That is why the present authors agree with the NACSN in that it is useful and reasonable to classify the metamorphosed and deformed sedimentary rocks separately into two subclasses; lithostratigraph-

Fig. 1. Simplified geological map of the surroundings of Lake Oulujärvi (see inset for location). The circled and uncircled numbers give, respectively, the stratigraphic unit and the deformation stage of the fault in question. Capitals A, B and C indicate, the Iisalmi, the Kuhmo-Ilomantsi, and the Pudasjärvi basement complexes, respectively. CPG = Central Puolanka Group, KTW = Kalhamajärvi Tectonic Wedge. The area of Fig. 3 is outlined. The Kainuu Schist Belt comprises the Karelian formations east and north of Lake Oulujärvi and the Northern Pohjanmaa Schist Belt consists of the Kaleva rocks at Utajärvi and Kiiminki northwest of the Auho Fault Zone. 


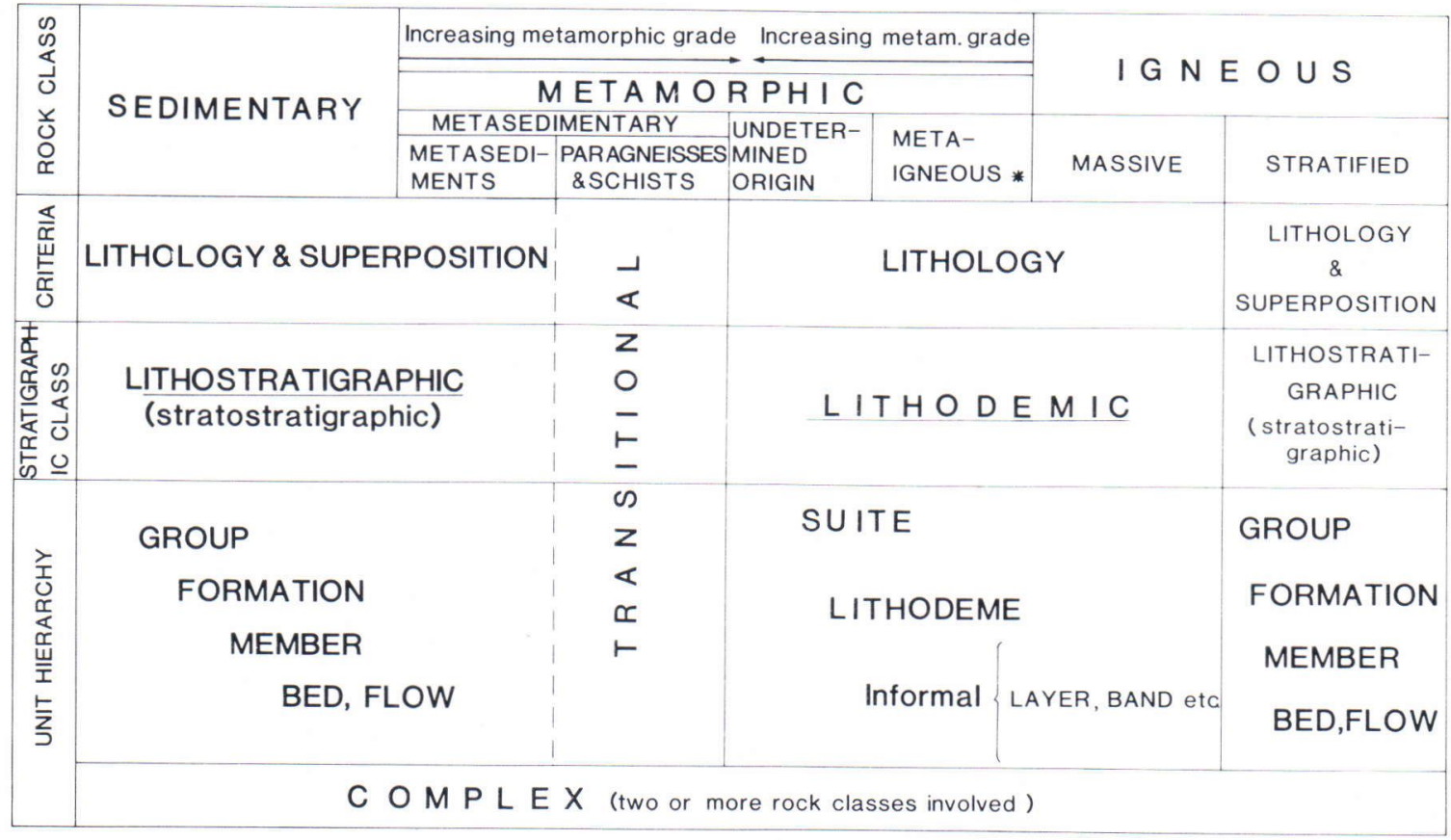

* If stratified apply lithostratigraphic procedure.

Fig. 2. Stratigraphic classifications and unit hierarchies applied in this study following the recommendations by the North American Commission on Stratigraphic Nomenclature (1983).

ic (or »stratostratigraphic») units consisting of strata which show sufficient primary features that their younging (or top) directions can be determined in the field, and lithodemic metasedimentary units which are so gneissic or deformed that their relative ages cannot be determined in the field (Fig. 2). On the other hand, the recommendations of the ISSC (1987) are followed in keeping the nomenclature of the stratigraphic units of metamorphic rocks as simple as possible (see also Laajoki, in press a).

\section{General geological setting}

The Salahmi-Pyhäntä area is located in central Finland about $50 \mathrm{~km}$ northwest of the town of Iisalmi. Its bedrock consists of early Proterozoic schists, gneisses and intrusive rocks bordering the northwestern margin of the late Ar- chaean Iisalmi Complex (2700-2500 Ma) (Fig. 1). In terms of tectonostratigraphy (see Laajoki 1986a), the study area belongs to the border zone between the Karelian schist areas in the east and the Svecofennian area of central Finland in the west. The schists and gneisses of the southern part of the study area appear on earlier maps (Mäkinen 1916; Wilkman 1929; Simonen 1980b) as a solitary triangular schist belt called either the Vieremä-Kiuruvesi schist belt (Savolahti 1965) or Salahmi schists (Väyrynen 1954). Korkiakoski and Laajoki (1988) redefined the Salahmi Schist Belt to include only the fairly well preserved autochthonous-parautochthonous metasediments fringing the Iisalmi Complex at Salahmi. At this stage we had not studied the relationship between the Salahmi schists and the gneisses to the west in the surroundings of Lake Näläntöjärvi. Mäkinen (1961) considers the latter older (Bothnian) than the former (Kalevian), whereas Wilkman 
(1929, 1931) regards both of them as Kalevian. Savolahti (1965) discussed this problem in detail but did not reach any clear conclusion.

Field work carried out in summer 1987 demonstrates clearly that the Näläntöjärvi gneisses represent lithodemic derivatives of the Salahmi schists and that they can be followed northwest to Pyhäntä and Piippola (Fig. 1, cf. Mäkinen's 1916 map). This gneiss belt, which is at least 60 km long and runs from Näläntöjärvi to Piippola is here called the Näläntö-Piippola Belt.

Structurally, applying the terminology and structural codes established by Laajoki et al. (1988), the Näläntö-Piippola Belt and the Salahmi Schist Belt with its northwestern extension, the Itämäki Schist Belt, form a large SE-NW trending $\mathrm{F}_{2}$ fold, called the Ahonkylä Antiform, pierced by the $\mathrm{D}_{4}$ faults of the Auho Fault Zone and intruded and migmatized by Svecokarelidic intrusive rocks in its central and southwestern parts.

The area north of the Ahonkylä Antiform is composed of diverse gneisses of problematical origin transposed to the Auho direction while further to the north and northwest the Northern Pohjanmaa Schist Belt occurs. The latter and the Salahmi schists have traditionally been correlated with each other (Mäkinen 1916). Northeast of the Itämäki Belt, the Otanmäki area consists mainly of granitic gneisses intruded by $2065 \mathrm{Ma}$ old metagabbros with Fe-Ti ores (Talvitie and Paarma 1980). The Kiuruvesi area, bordering the study area to the south, consists mainly of gneisses and metavolcanics intruded by Svecokarelidic intrusive rocks (Marttila 1976, 1981) and belongs structurally to the Raahe-Ladoga Zone, which is a conjugate NW-SE trending fault system of the Auho Fault Zone. About $120 \mathrm{~km}$ to the southeast is the Kuopio area with Archaean basement domes mantled by Karelian supracrustal rocks.

The early Proterozoic bedrock of the study area proper shown in Fig. 3 consists of three major stratigraphic entireties: 1) The supracrustal rocks rimming the Archaean basement in the east. These rocks can be classified by lithostratigraphic procedure. 2) Two gneiss complexes in the central part of the study area and their less metamorphosed gneiss and schist mantle. The northern part of this group belongs to the Auho Fault Zone and is strongly folded and faulted and intruded by Svecokarelidic granitoids. 3) The southwestern and western part of gneisses and schists with Svecokarelidic intrusive rocks. In this paper the stratigraphy of the supracrustal rocks of each entireties will be established with an emphasis on the eastern relatively allochthonous units and the central gneiss complexes and their mantle. The western gneisses and schists and the Svecokarelidic intrusive rocks will be treated only in brief. Table 1 summarizes the stratigraphic units described in the paper. The reader is adviced to consult this table as well as figures 1, 3 and 21 when reading this paper.

\section{Archaean basement}

The depositional basement of the early Proterozoic metasedimentary rocks is exposed in the southeastern margin of the study area where the late Archaean granitoid gneisses of the Iisalmi Complex occur. We mapped only the marginal zone of this complex; for its general lithology the reader is referred to the descriptions of Wilkman (1931). The narrow granitoid, gneiss wedge north of Saaresmäki is also included in the basement in Fig. 3, but this correlation is unsure.

The Archaean gneisses are mainly tonalitic, rather massive gneisses with subordinate amphibolites and pegmatites. Locally there are also banded gneisses with alternating mica gneiss and quartz-feldspar gneiss bands.

\section{Lithostratigraphy of the early proterozoic formations rimming the Archaean basement}

In this chapter those early Proterozoic metasedimentary rocks which deposited on the 


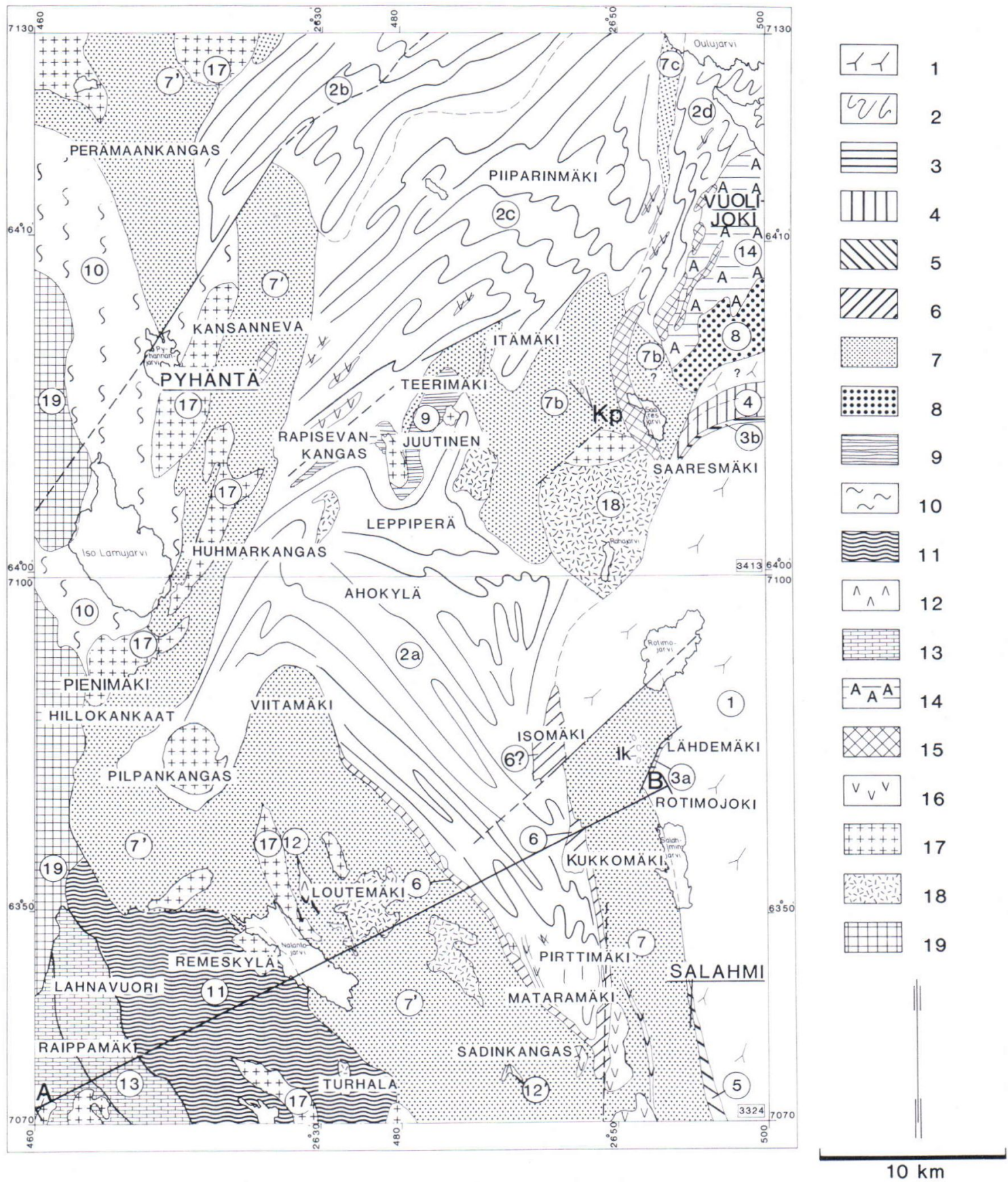

Fig. 3. Geological map of the Salahmi-Pyhäntä area (map sheets 3324 and 3413) based mainly on the mapping by J. Luukas (1986-87), K. Laajoki (1985-87), and E. Korkiakoski (1985). The area of the map is $40 \times 60 \mathrm{~km}$. 1. Archaean basement. 2. Pirttimäki Complex (2a) and Piiparinmäki Complex with western (2b), central (2c) and eastern (2d) subcomplexes. 3. Lähdemäki (3a) and Potakka-aho (3b) formations. 4. Lautakangas formation and its lithodemic derivatives. 5. Haajainen Formation. 6. Mataramäki gneiss. 7. Rotimojoki Formation (7) and its lithodemic derivates (Näläntö-Piippola Belt) (7') with chert intermembers (black), Itämäki Formation (7b) and Ojanperä formation (7c). Ilkonahonkallion (Ik) and Kaukolanpuron $(\mathrm{Kp})$ conglomerates are shown by open circles. 8. Katajakangas formation. 9. Rapisevankangas Gneiss Suite. 10. Lamujärvi Complex. 11. Turhala Gneiss. 12. Loutemäki (12) and Sadinkangas (12') gneisses. 13. Diverse Svecofennian supracrustal rocks. 14. Otanmäki Alkaline Gneiss. 15. Metagabbro. 16. Amphibolite. 17-19. Svecokarelidic intrusive rocks: 17. Granite, pegmatite and granodiorite. 18. Diorite and quartz diorite. 19. Diverse plutonic rocks, mainly granitoids. The location of the prophile in figure 20 is shown by line $\mathrm{A}-\mathrm{B}$. 
Table 1. List of the major rock units of the Salahmi-Pyhäntä area. The stratigraphic correlation of a unit indicated by an asterix is questionable.

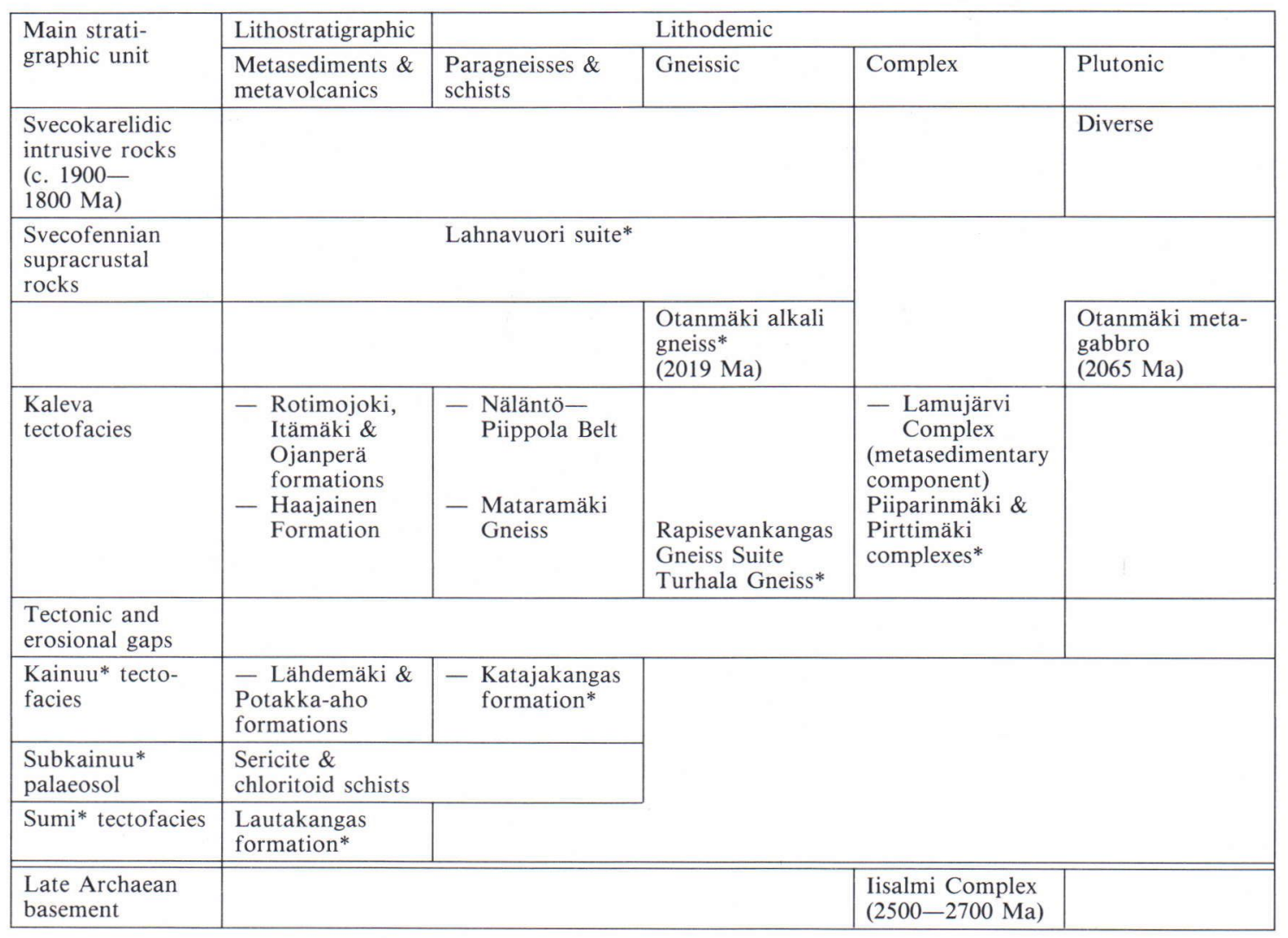

Archaean basement and which show evident primary features to be treated as lithostratigraphic units are described. These formations are encountered in two areas; in the Salahmi-Lähdemäki area where they form the Salahmi Schist Belt and north of Saaresmäki (Fig. 3). At Salah$\mathrm{mi}$, the sequence is divided into three formations: the Lähdemäki Formation (the lowermost), the Haajainen Formation and the Rotimojoki Formation, which forms the bulk of the Salahmi Schist Belt. Three formations, the Lautakangas, Potakka-aho and Katajakangas, are encountered north of Saaresmäki, but due to scanty outcrops their stratigraphic relations are not as clear as at Salahmi. We first describe the Salahmi Belt and then the Saaresmäki area.

\section{Lähdemäki Formation ( $L m F$ )}

This autochthonous-parautochthonous formation has been recently defined and described in detail by Korkiakoski and Laajoki (1988). Thus, only its main lithostratigraphic features are summarized.

The depostion of the LmF was proceeded by a period of intense chemical weathering of the Archaean depositional basement which produced a palaeosol rich in sericite or, when developed on the Archaean amphibolites, rich in chloritoid. The palaeosol (regolith) was mainly eroded and mixed into the overlying psammitic sediments during the deposition of the LmF. Locally, however, a basal sericite schist bed occurs (Fig. 4) 


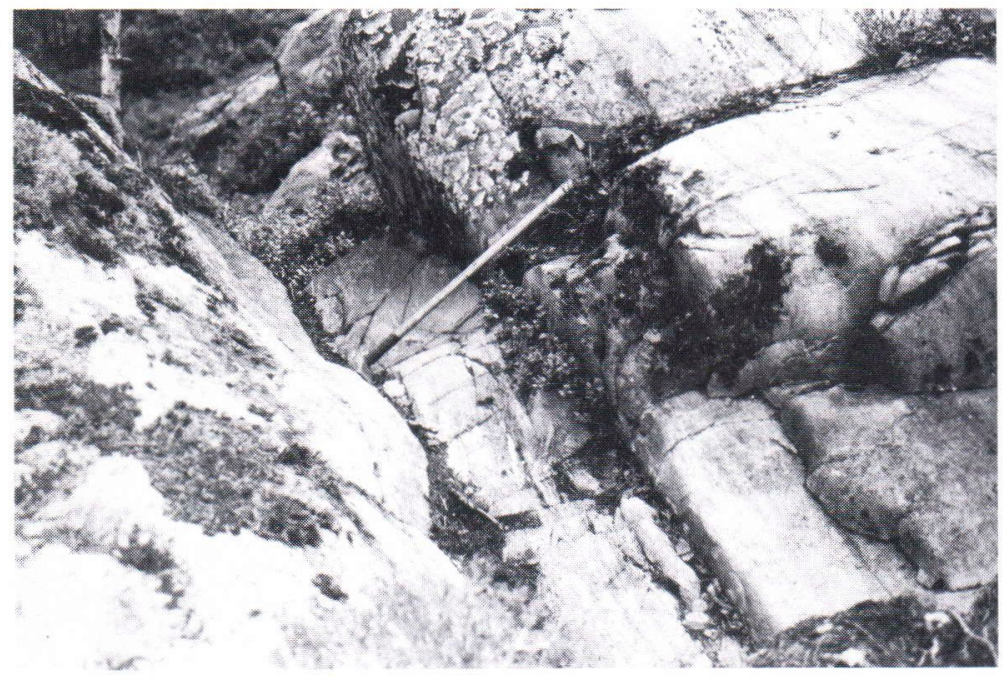

Fig. 4. The basal sericite schist regolith (about $40 \mathrm{~m}$ wide zone in the center) between the Iisalmi Complex (on the left) and the lowermost quartzite of the Lähdemäki Formation. Lähdemäki. which is about $0.5-1 \mathrm{~m}$ thick and which probably served as a lubrication surface along which the formation was slightly moved during the Svecokarelidic folding. In other places, the formation begins with thin in situ basal breccia (Fig. 5).

As a whole the $\mathrm{LmF}$ is a fluvial sequence, about 40-80 m thick, divided into two members. The lower member consits of feldspathic quartzites with conglomerate interbeds whose phenoclasts are Archaean basement granitoids and vein quartz. The upper member contains arkosites and metasiltstones with minor conglomerates. The upper contact of the LmF against the Rotimojoki Formation is tectonic. The formation displays many well-preserved sedimentary structures documentated by Korkiakoski and Laajoki (1988).

\section{Haajainen Formation ( $\mathrm{HjF})$}

The northern end of the Haajainen Formation $(\mathrm{HjF})$, recently established by Korkiakoski and Laajoki (1988), projects from its type area at Haajainen to the southeastern corner of the study area (Fig. 3). The HjF is a turbiditic metapsephite and metapsammite unit which contains a lot of conglomerates together with metapsammites at Haajainen, but at the study area the rocks are, however, mostly turbiditic meta-arenites and metapelites. Its lower part is intensely tectonized and the $\mathrm{HjF}$ is probably parautochthonousallochthonous. At Metelinmäki it grades into Rotimojoki Formation, but the relationship is disturbed by intrusion of Svecokarelidic granitoids.

\section{Rotimojoki Formation (RjF)}

This formation with well-preserved primary structures was established by Korkiakoski and Laajoki (1988) who give a detailed description of its sedimentology and stratigraphy. Their results are summarized here.

The lower contact of the $\mathrm{RjF}$ with the $\mathrm{HjF}$ is most likely gradational, whereas structural and topographic evidence suggests that it is separated by a tectonic contact from the LmF at Lähdemäki (Fig. 3). The contact with the Mataramäki Gneiss and the major western part of the $\mathrm{RjF}$ is practically unexposed.

The type section of the basinal RjF is Lähdemäki-Ilkonahonkallio where the formation, which is about $1000 \mathrm{~m}$ thick, is divided into three 
Fig. 5. Sedimentary breccia with basement orthogneiss clasts at the bottom of the Lähdemäki Formation, Lähdemäki.

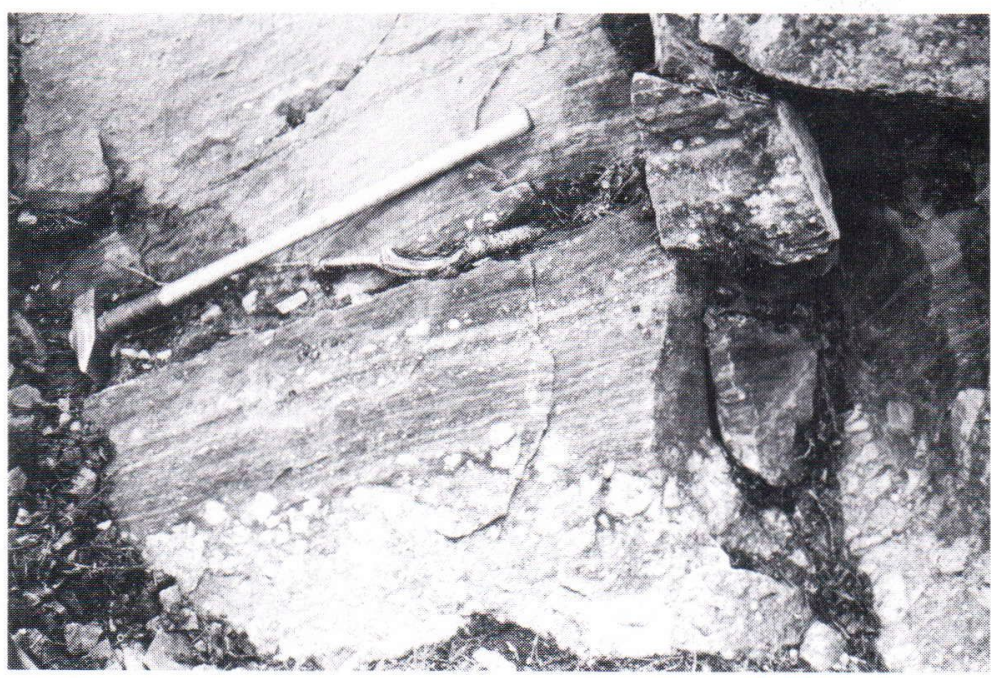

members: 1) The lower member consisting mainly of massive arkosites originally turbidites of smooth mid/lower fan, 2) The middle member consisting mainly of massive arkosites originally turbidites of channeled mid fan and 3) The Ilkonahonkallio member consisting mainly of quartzite-phenoclasted turbiditic conglomerates and massive-graded arkosites of upper/mid fan channels and laminated - thinly bedded and graded mica schists interpreted as levee and interchannel turbidites of upper/mid fan. The poorly exposed western and southwestern part contains a few amphibolite bodies and sporadic mica schist outcrops.

As a whole the $\mathrm{RjF}$ is included with the western Kaleva tectofacies of the nearby Kuopio, Northern Pohjanmaa and Perä-Pohja provinces.

\section{Lautakangas formation ( L kf)}

At Lautakangas, about $500 \mathrm{~m}$ northeast of Potakka-aho, basic metavolcanite occurs in a few outcrops $(\mathrm{x}=7109.1, \mathrm{y}=499.1)$. On the basis of the geophysical maps this unit is seen to continue southeast outside the study area and may be better exposed there. The formation is, therefore, not defined formally here but is treated as an informal unit called the Lautakangas formation (Lkf). The metavolcanics are intensely deformed, fine-grained basic rocks amphibole, quartz and plagioclase as the main minerals. Its southern contact with the Potakka-aho Formation is covered by marshy terrain.

North of Lautakangas banded hornblendefeldspar gneisses, consisting of alterating amphibolitic and quartz-feldspar gneiss layers, occur. They are included in this formation as a more metamorphosed part of the original volcanic succession.

\section{Potakka-aho Formation (PoF)}

Definition: North of Saaresmäki are a few solitary outcrops of feldspar metapsammites lithologically similar to those of Lähdemäki. Because this occurrence is physically separated from the $\mathrm{LmF}$ it is classified as a lithostratigraphic unit in its own right, named the Potakka-aho Formation (PoF).

Name and outcrops: The formation takes its name from the small locality $(\mathrm{x}=7108.4$, $\mathrm{y}=$ 498.5) where its only outcrops known occur. So far, the PoF is known to be exposed in only three 
small outcrops at Potakka-aho and at the bottom of the ditches of a forest road.

Contacts and thickness: The contacts of the $\mathrm{PoF}$ are not exposed. By analogy with the LmF, it is concluded that the PoF was deposited on the Iisalmi Complex and so its lower contact is a nonconformity. The thickness of the formation is at least a few hundred metres.

Structure: The PoF is folded into a vertical position and faces northwards from the Iisalmi Complex.

Lithology: The PoF consists of two major lithologies: 1) Light brown or reddish feldspar quartzite and arkosite with distinct bedding and rare cross-bedding. 2) Closer to the basement, mica schist and micaceous metapsammite.

Correlation: On the basis of its lithological similarities and stratigraphical position close to the Archaean basement the PoF is correlated with the $\mathrm{LmF}$, but the geophysical maps indicate that physically it more likely belongs to the unit which includes the quartzites and conglomerates of lake Alanteenjärvi (Wilkman 1924), about $70 \mathrm{~km}$ southeast from Potakka-aho (see unit 2 on Fig. 1).

\section{Katajakangas formation (Kkf)}

This formation occurs mostly outside the study area where it has been described by Puumalainen (1986). It is a psammitic metaturbidite unit with frequent amphibolite layers. It shows typical $T_{a}$ or $T_{a e}$ features at Katajakangas, the type locality, but, in the west, it is metamorphosed and granitized to quartz-feldspar gneisses and partly altered to Otanmäki alkali gneiss. The westernmost parts are also unexposed; so the relationship of the formation to the Itämäki Formation cannot be established.

On the basis of lithology the Kkf could be correlated with the Itämäki Formation, but it also closely resembles the Puolankajärvi Formation (Laajoki and Korkiakoski 1988). This problem is discussed more in the section $»$ Interregional correlation».

\section{Stratigraphy of the central gneiss complexes and their lithodemic mantle}

The major central part of the study area is composed of banded or weakly banded quartzfeldspar gneisses with frequent amphibolite layers. The gneisses have been intruded, migmatized and granitized by Svecokarelidic granitoids. In earlier studies these gneisses have been included in the Archaean basement, but this study indicates that this concept is probably not valid. These gneisses are encountered in two areas, south and north of the Itämäki-Rapisevankangas schists and gneisses. Because the rocks of these areas differ in lithology and their contact relations are open they are here classified into two separate units called the Pirttimäki (the southern one) and Piiparinmäki (the northern one) complexes. Structurally the former forms the core of the Ahonkylä antiform.

These complexes grade to and are mantled by paragneisses and schists. These are classified into the Mataramäki Gneiss, which rims the Pirttimäki Complex in the southeast, the Rapisevankangas Gneiss Suite and the Itämäki Formation, which occupy the border zone between the Pirttimäki and Piiparinmäki complexes, the Näläntö-Piippola Belt which rims these complexes in the southwest and west and the Ojanperä formation in the northeast. In this context we also describe two gneisses of undetermined origin: the Loutemäki and Sadinkangas gneisses which occur within the Näläntö-Piippola Belt.

\section{Pirttimäki Complex (PmC)}

Definition: The banded gneisses and schists with relatively common amphibolite layers and associated Svecokarelidic intrusive rocks, occupying the area from Mataramäki in the southeast to Leppiperä and Juutinen in the centre of the study area (Fig. 3), form the Pirttimäki Complex (PmC).

Name and outcrops: The complex takes its name from the small settlement area where it is 
best exposed. In addition to the type locality at Pirttimäki (map sheet 3324 07) the complex is well-exposed also at Pilpankangas, Viitamäki, Leppiperä and Juutinen. Other parts of the complex are poorly exposed, for example, wide areas in the surroundings of Ahokylä are totally unexposed.

Contacts: All contacts are either lithodemic or tectonic. In the southeast the contact is situated below the Mataramäki Gneiss. Although this contact is not directly exposed, the lithological and structural relationships clearly indicate that the PmC and the Mataramäki Gneiss belonged originally to the same sedimentary sequence of which the latter is a better preserved part. In the north the PmC changes gradually to the Rapisevankangas Gneiss Suite and is separated by a fault from the Piiparinmäki Complex. In other areas the contact zone is not exposed.

Structure: The PmC forms the southeastern end of the southeasterly plunging Ahonkylä $F_{2}$ antiform refolded and faulted by $D_{3}$ and $D_{4}$. The thickness of the original sedimentary sequence cannot be measured but it was at least a few hundred metres.

Lithology and origin: The metamorphic grade of the complex is upper amphibolite facies and the gneisses are often migmatized by Svecokarelidic granitoids. The PmC consists of four major lithologies: 1) The dominant lithology is banded quartz-feldspar gneiss with mica-rich bands (Fig. 6). The gneisses contain both plagioclase and microcline and show hetero- or granoblastic texture. The mica-rich bands are biotite schists with variable amounts of feldspars and quartz. No primary structures have been preserved but the banded appearance, the pelitic composition of mica-rich bands and the textures point to the fact that the gneisses are metasedimentary. 2) Reddish granitic microcline-rich gneisses abound in close association with quartz-feldspar gneisses whose granitized derivatives they most probably are. 3) Amphibolite bodies conformable with the banding of the enclosing gneisses are frequent in the southeastern part of the complex. Some of them are banded but mostly they are generally homogeneous and strongly foliated. Because no primary structures or textures are visible the origin of the rocks cannot be determined. 4) Svecokarelidic granitic intrusive rocks have intruded the southwestern part of the $\mathrm{PmC}$, in particular, where pegmatite bodies occur at the PmC-Mataramäki Gneiss-contact.

Correlation and age: The overall lithology of the PmC and the way it grades to the mantling gneisses shows that it does not belong to the Archaean basement, but represents lithodemic derivatives of the early Proterozoic sedimentary rocks (cf. Wilkmann 1931, Simonen 1980b).

\section{Piiparinmäki Complex (PpC)}

Definition: The granitic gneisses with abundant amphibolite layers, intruded and migmatized by Svecokarelidic granitoids north of Rapisevankangas form the Piiparinmäki Complex (PpC).

Name and outcrops: The $\mathrm{PpC}$ derives its name from Piiparinmäki (map sheet 3413 09B), the locality which occupies the central area of the complex. The complex is fairly evenly exposed, but the outcrops are mostly solitary and separated from each other by wide unexposed marshy terrains.

Contacts: The contacts of the complex are unexposed. The complex can, however, be delineated sharply from its surroundings with the aid of geophysical maps. Geophysics and structural observations indicate that its southern contact with the Itämäki schists, Rapisevankangas gneisses and the PmC is mostly tectonic, but the contact with the Näläntö-Piippola Belt may be gradational.

Structure: The PpC forms the core of a polyphacial fold structure whose earlier structures were intensively transposed by $\mathrm{D}_{4}$ parallel to major $\mathrm{S}_{4}$ faults of the Auho Fault Zone. The transposition of its eastern and western margins was more intensive than in the centre where earlier structures are still visible.

Lithology and origin: The gross lithology of 


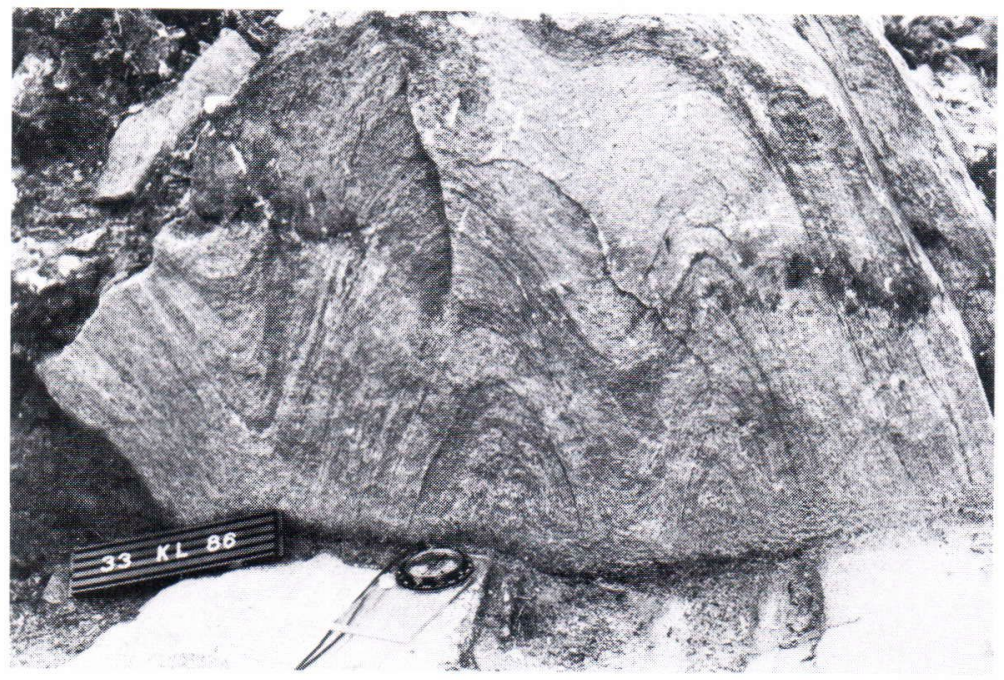

Fig. 6. A banded biotitequartz-feldspar gneiss showing a $\mathrm{F}_{2}$-fold. Pirttimäki Complex, Kaidanmäki. The length of the label of this and all other photographs to follow is $17 \mathrm{~cm}$. the $\mathrm{PpC}$ resembles that of the $\mathrm{PmC}$, but its gneisses are more recrystallized and do not show as clear a banded structure. They are also more granitized. The complex consists of 1) quartzfeldspar gneisses, 2) amphibolite layers and 3) Svecokarelidic intrusive rocks. On the basis of geophysical maps and lithology the $\mathrm{PpC}$ seems to consist of three subcomplexes, called informally the eastern, central and northwestern subcomplexes (their boundaries are delimited by broken lines on Fig. 3).

The eastern subcomplex consists of banded quartz-feldspar (plagioclase and microcline) gneisses with abundant amphibolite layers and is intruded by gabbros (Puumalainen 1986). In the east these gneisses are bounded by alkali gneisses. The central subcomplex consists of light, weakly banded oligoclase gneisses (Fig. 7) poorer in microcline than the eastern part. Amphibolite layers are also common. The gneisses of the northwestern subcomplex are intensely granitized quartz-feldspar gneisses often showing banded structure and containing subordinate amphibolite layers.

The origin of the $\mathrm{PpC}$ gneisses is problematical. Its marginal parts show paragneissic features whereas the core zone has coarse oligoclase gneisses which resemble those of the Archaean basement.

Correlation and age: In its gross lithology the $\mathrm{PpC}$ resembles the $\mathrm{PmC}$ at the latter's northern, more recrystallized and deformed extension. On the other hand, the oligoclase gneisses of the central subcomplex could be correlated with the Archaean rocks of the Iisalmi Complex. This cannot, however, be verified without isotope data. At this stage, a reasonable working hypothesis is that the marginal zones of the $\mathrm{PpC}$ represent Proterozoic gneisses correlative with the PmC and that the core is Archaean. The PpC can be mapped northeastwards as far as southwest Puolanka where its relationship with the Southwestern Paragneiss Complexe has not yet been established (Laajoki 1986b).

\section{Rapisevankangas Gneiss Suite (RGS)}

Definition: The Rapisevankangas Gneiss Suite was described and defined by Luukas (1987) and his classification is followed here. This suite includes the banded gneisses and schists occupying the border zone between the Pirttimäki and 
Fig. 7. Oligoclase gneiss with amphibolite layers and showing $\mathrm{F}_{3}$-folds. Piiparinmäki Complex, west of Itämäki.

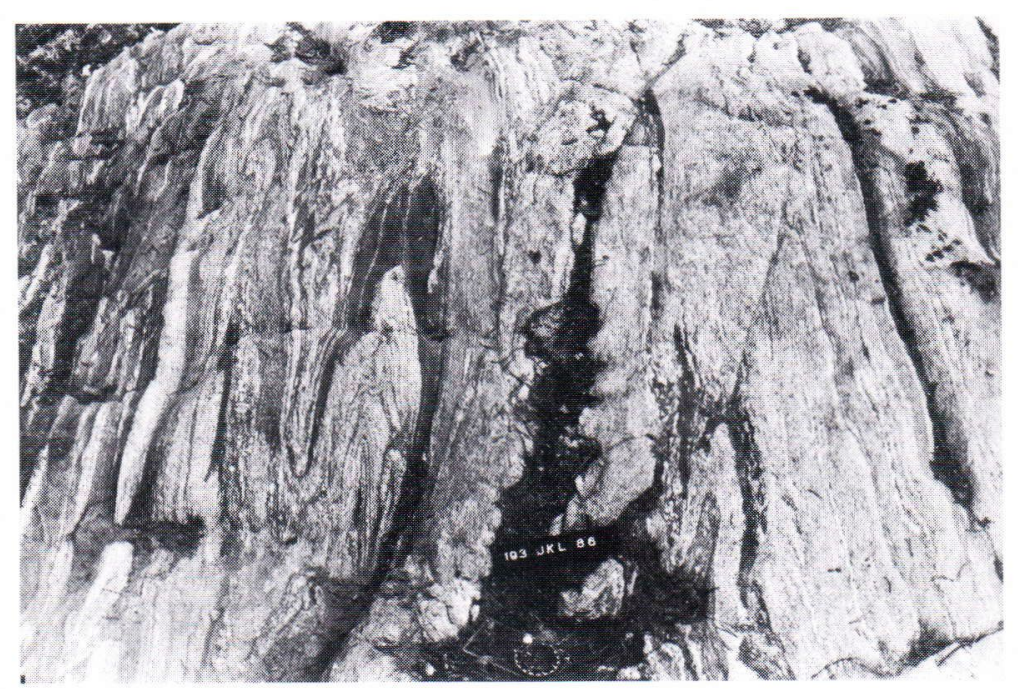

the Piiparinmäki complexes at Rapisevankangas, west of Itämäki (Fig. 3).

Name and outcrops: The suite takes its name from Rapisevankangas ( $\mathrm{x}=7107.6, \mathrm{y}=478.2$ ) where its individual gneiss lithodemes are best exposed. This suite is exceptionally well exposed and so its lithology can be classified in more detail than any other gneiss unit in the study area.

Contacts and thickness: The southern contact with the Pirttimäki Complex is considered gradational and metamorphic and the northern contact with the Piiparinmäki Complex tectonic. The contact with the Itämäki Formation is not exposed, but is interpreted as lithodemic. The total thickness of the suite is estimated to be about 500-800 m.

Structure: The suite defines an $\mathrm{F}_{2}$ structure refolded intensely by $\mathrm{D}_{4}$. The $\mathrm{F}_{4}$ fold axes are subhorizontal and partly coaxial with $\mathrm{F}_{2}$.

Metamorphism: Metamorphism is higher than at Itämäki as revealed by the almost complete lack both of primary structures and staurolite in the mica schists and the common banded structure of the gneisses.

Lithodemes: The suite consists of seven lithodemes (Fig. 8) (regrettably, due to lack of locality names we have to use 'Rapisevankangas' as

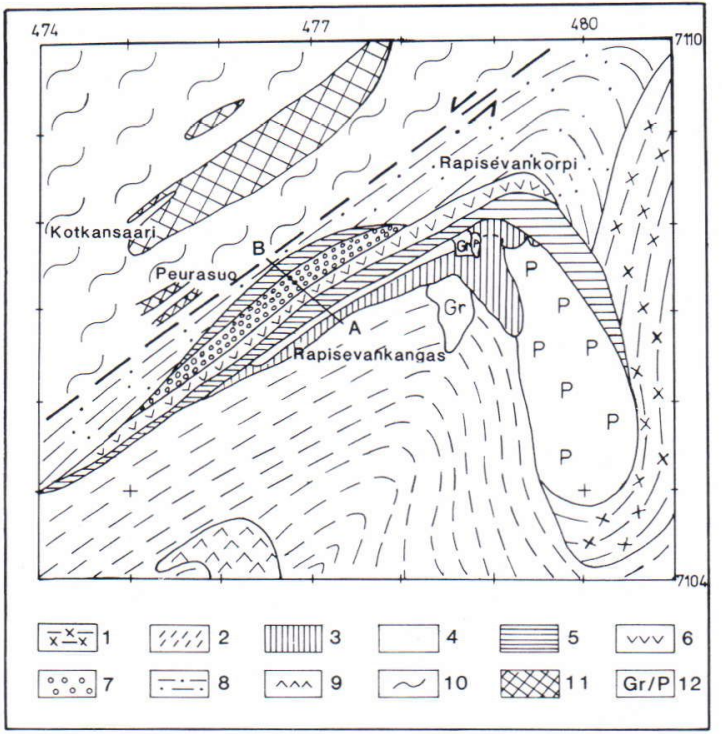

Fig. 8. A map showing the field relationship of the lithodemes of the Rapisevankangas Gneiss Suite. Symbols: 1. Teerimäki Biotite-Plagioclase Gneiss. 2. Leppiperä QuartzFeldspar Gneiss. 3. Rapisevankangas banded hornblende gneiss. 4. Rapisevankangas quartz-feldspar gneiss. 5. Rapisevankangas mica schist. 6. Rapisevankangas hornblende gneiss. 7. Pitkäkangas Mica Schist. 8. Paavonsuo QuartzFeldspar Gneiss. 9. Petäjäkangas Quartz Dioritic Gneiss. 10. Piiparinmäki Complex. 11. Amphibolite. 12. Granite and pegmatite. The map area is $7 \times 6 \mathrm{~km}$ and the broken line indicates the tectonic contact between the Piiparinmäki Complex and the RGS. 
the geographic code of four first lithodemes). 1) The Rapisevankangas banded hornblende gneiss consists of alternating dark hornblende-quartzplagioclase layers and much thinner and lighter biotite-plagioclase layers (Fig. 9). 2) The Rapisevankangas quartz-feldspar gneiss is a lightcoloured banded lithodeme. 3) The Rapisevankangas mica schist is a biotite mica schist with abundant thin psammitic layers (Fig. 10). No prophyroblasts occur. 4) The Rapisevankangas hornblende gneiss consists of weakly banded or massive hornblende-bearing quartz-plagioclase gneiss with enough magnetite to cause distinctive positive anomalies on aeromagnetic maps. 5) The Pitkäkangas Mica Schist is a fairly homogeneous biotite schist with thin conformable amphibolite layers. 6) The Paavonsuo QuartzFeldspar Gneiss is a reddish biotite-banded quartz-feldspar gneiss. 7) The Teerimäki BiotitePlagioclase Gneiss is a paragneissic banded gneiss of probable turbiditic origin.

The lithodemes contain subordinate amphibolite layers or lenses conformable to the banding of the gneisses and are often intruded by pegmatite veins.

The RGS, with its many lithodemes, provides a good example of how manifold the stratigraphic classification of a metamorphic rock suite may be even within a relatively small area.

Correlation: The RGS is considered to represent a lithodemic transition between the $\mathrm{PmC}$ and the Itämäki Formation. Its mica schists are obviously the western extension of the ImF but its gneisses cannot readily be correlated with any of the specific gneiss types of the PmC except the Teerimäki Biotite-Plagioclase Gneiss which resembles the paragneisses at Pirttimäki.

\section{Itämäki Formation (ImF)}

Definition: This formation has recently been described by Luukas (1987), whose description and definitions are applied here. The Itämäki Formation (ImF) comprises all the mica schists, mostly staurolite-bearing, and associated metapsephites and metapsammites which are folded in a complex way between the central gneiss complexes. This belt greatly resembles the Rotimojoki Formation, but is separated from it by gneisses and intrusive rocks and tectonic zone(s). However, its psephitic members differ significantly from those of the $\mathrm{RjF}$ and hence these two units are described separately.

Name and outcrops: The formation takes its name from the locality where it is best exposed and where Wilkman $(1929,1931)$ described these rocks earlier. Outside the type area at Itämäki $(\mathrm{x}=7112.8, \mathrm{y}=484.8)$, only solitary ImF outcrops are encountered.

Contacts and thickness: The contacts with the central gneiss complexes are not exposed whereas those with the Rapisevankangas Gneiss Suite are metamorphically gradational. The eastern part of the formation is devoid of outcrops and therefore its relationship to the formations north of Saaresmäki is not known. The thickness of the ImF cannot be measured; it is estimated to be of the order of hundreds of metres or even more than one kilometre.

Structure: The ImF forms an $\mathrm{F}_{2}$ synform refolded by $\mathrm{D}_{3}$ and $\mathrm{D}_{4}$.

Bulk lithology: Staurolite mica schist with rare relict bedding or graded bedding structures (Fig. 11) forms the major lithology. Staurolite porphyroblasts have often been replaced by prograde muscovite. Sillimanite segregations are also common.

Metapsammite members: The ImF contains distinctive quartz-feldspar metapsammite members at three localities. The thickest member occurs at Itämäki where a few tens of metres thick unit consists of massive or graded $\mathrm{T}_{\mathrm{a}}$ turbidites. The stratigraphic position of the members within the ImF is not clear but at least the member at Itämäki is located close to the Piiparinmäki Complex.

Kaukolanpuro metapsephite members: East of Itämäki, close to the Kaukolanpuro streamlet, amidst the bulk mica schists two separate con- 
Fig. 9. Banded hornblende gneiss. Pitkäkangas.
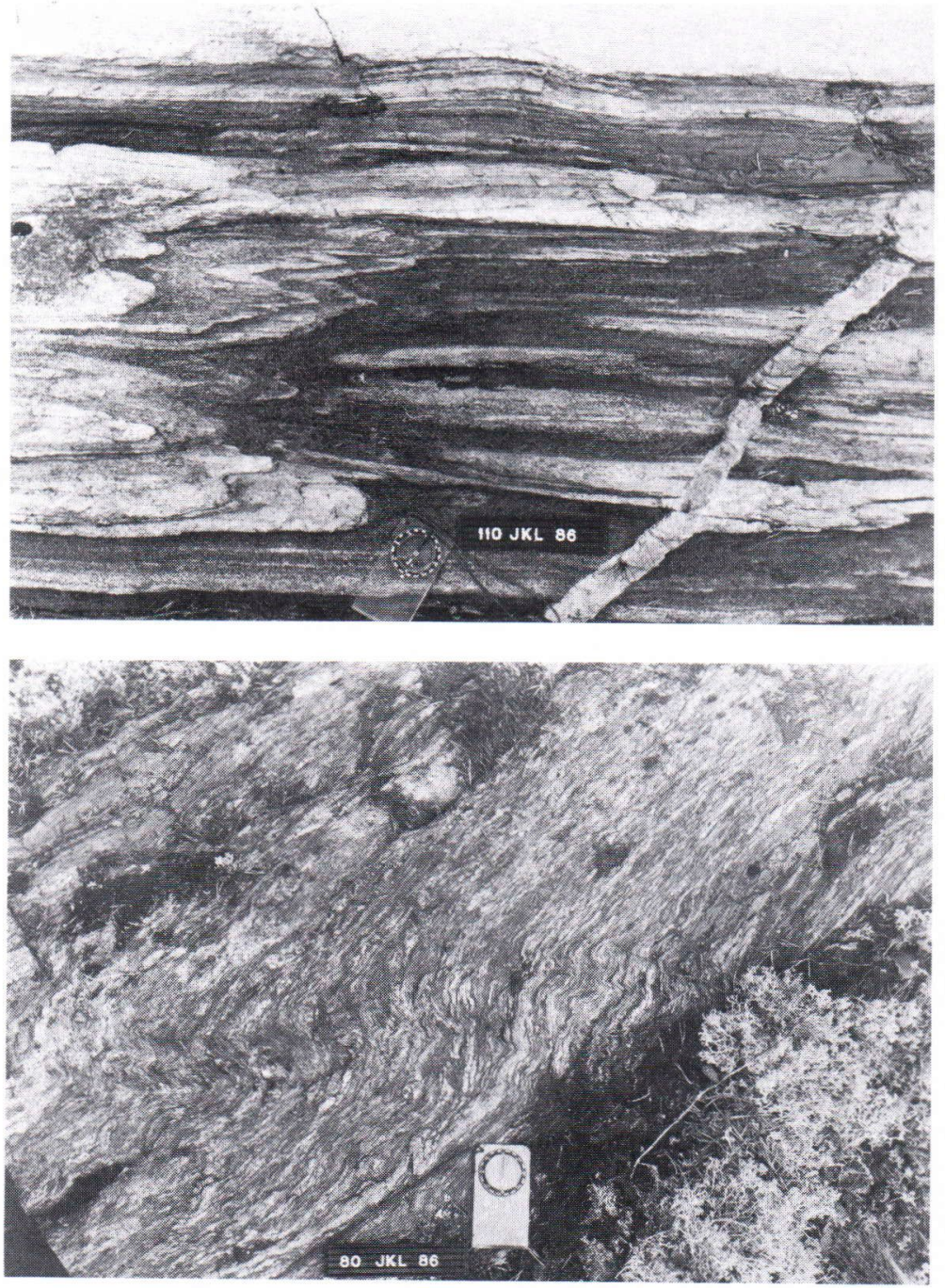

Fig. 10. Intensely deformed mica schist. Rapisevankangas.

The quartzite beds are of the same dark massive biotite-quartzite as the matrix of the conglomerate and they are interpreted as $\mathrm{T}_{\mathrm{a}}$ turbidites. The thickness of this member is at least $30-40$ metres.

The western member is thinner, its phenoclast size is smaller (less than $10 \mathrm{~cm}$ ) and the skarn rock phenoclasts are lacking. The conglomerate occurs as an interbed in staurolite mica schist and no quartzite beds are encountered. 

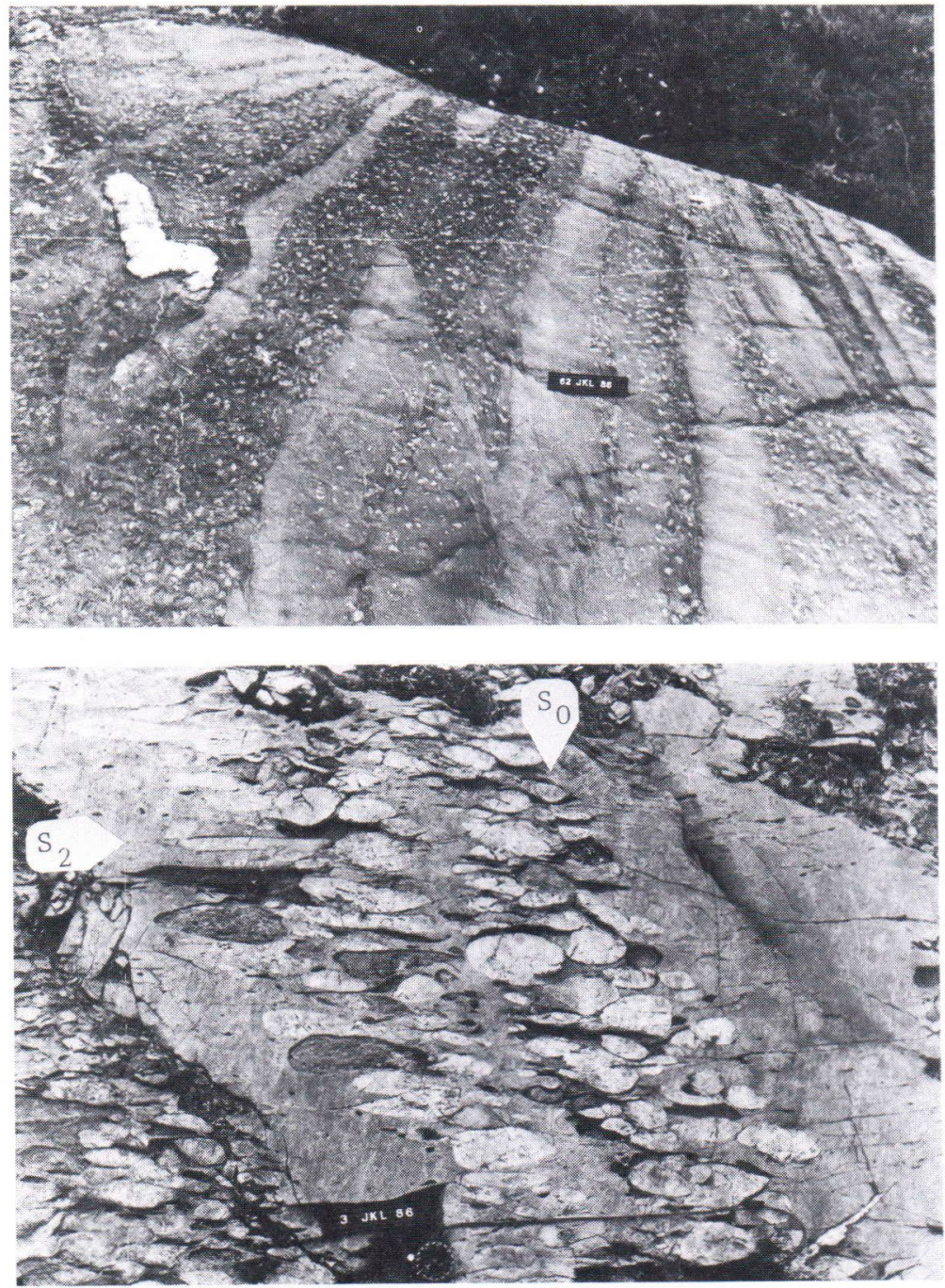

Fig. 11. Staurolite mica schist with psammitic interbeds, Itämäki Formation. Loukkukangas (Luukas 1987).

Fig. 12. Metaconglomerate of the eastern metapsephite member of the Itämäki Formation, Kaukolanpuro. The white phenoclasts are orthoquartzite, the dark ones skarn-type rock (Luukas 1987).
Correlation: The ImF is correlated chronostratigraphically with the Rotimojärvi Formation, but the Kaukolanpuro members differ so much from the Ilkonahonkallio Member that they may represent separate, but closely related depositional systems.

\section{Ojanperä formation (Ojf)}

This is a small psammitic metaturbidite occurrence which outcrops within the PpC-type gneiss- es at Ojakangas, $3 \mathrm{~km}$ north of the northern margin of the study area. Its southern extension, marked on Fig. 3, is based purely on geophysical interpretations. Lithologically this unit resembles the psammitic metaturbidites of the ImF and the Näläntö-Piippola Belt at Kansanneva and is correlated with the $\mathrm{ImF}$.

\section{Mataramäki Gneiss (MmG)}

Definition: Between the $\mathrm{PmC}$ and the 
Fig. 13. Mica gneiss folded along a horizontal fold axis and showing a psammite interbed. Mataramäki Gneiss, Kukkomäki.

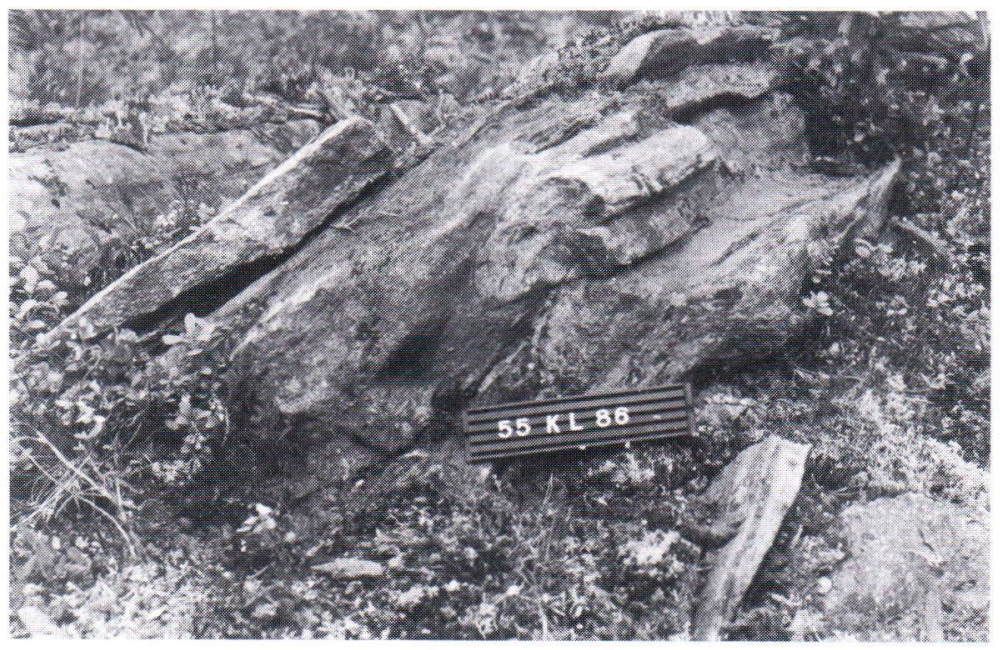

Rotimojoki Formation and its western lithodemic derivatives there occurs a narrow but distinctive unit of psammitic banded gneisses of turbidite origin. This marker unit is called the Mataramäki Gneiss.

Name and outcrops: This lithodemic unit takes its name from both the hill of Mataramäki on whose western flank it is best exposed and from its gneissic lithology. The type outcrops occur at Mataramäki ( $\mathrm{x}=7076.7, \mathrm{y}=487.9$ ) on both sides of a forest road from Heinälampi to Jokela. Other parts of the lithodeme are poorly exposed with the exception of Kukkomäki ( $\mathrm{x}=$ 7084.9, y $=489.1$ ).

Contacts and thickness: The contact with the $\mathrm{PmC}$ is intruded by pegmatite granites or is unexposed and so the relationship of these two units is not known. The contact with the Rotimojoki Formation and its correlatives is also not exposed. The thickness of the unit is a few tens of metres at least.

Structure: The MmG is multiply deformed and at Mataramäki shows complex interference fold patterns. At Kukkomäki, it is folded along a subhorizontal late fold axis (Fig. 13) and east of Pirttimäki it is cut by a N-S trending fault. Excluding the Kukkomäki area, the composite N-S striking gneiss banding is almost vertical and at Ma- taramäki it dips about $50-70^{\circ}$ to the southwest. As a whole the $\mathrm{MmG}$ forms an $\mathrm{F}_{2}$ structure enveloping the $\mathrm{PmC}$ antiform and deformed by $\mathrm{D}_{3}$.

Lithology and origin: The MmG consists of psammitic-psephitic turbidites metamorphosed to variable degrees. The western part is gneissic and migmatized and granitized by the Svecokarelidic pegmatites, whereas the eastern part consists of less metamorphosed schists (Fig. 13). The best preserved metasediments in the west occur at Tiukumäki, northwest of Mataramäki, where distinctive graded or massive $\mathrm{T}_{\mathrm{a}}$ turbidite beds are still visible (Fig. 14). These are quartz-plagioclasemicroline metapsammites. The microcline is mostly secondary. At Patvinperä, east of Mataramäki, there are graded bedded strata which are conglomeratic in their lower parts (Fig. $15)$.

The conglomerate of Kukkomäki was described in detail by Savonlahti (1965). It is intensely deformed and does not show clear primary sedimentary features. The phenoclasts are mainly felsic quartz-plagioclase-microcline gneisses with subordinate mica schist fragments and the matrix is a micaceous psammite. The conglomerate occurs as thin, intensely deformed interbeds in mica schists (Fig. 13, see also Savolahti's (1965), 

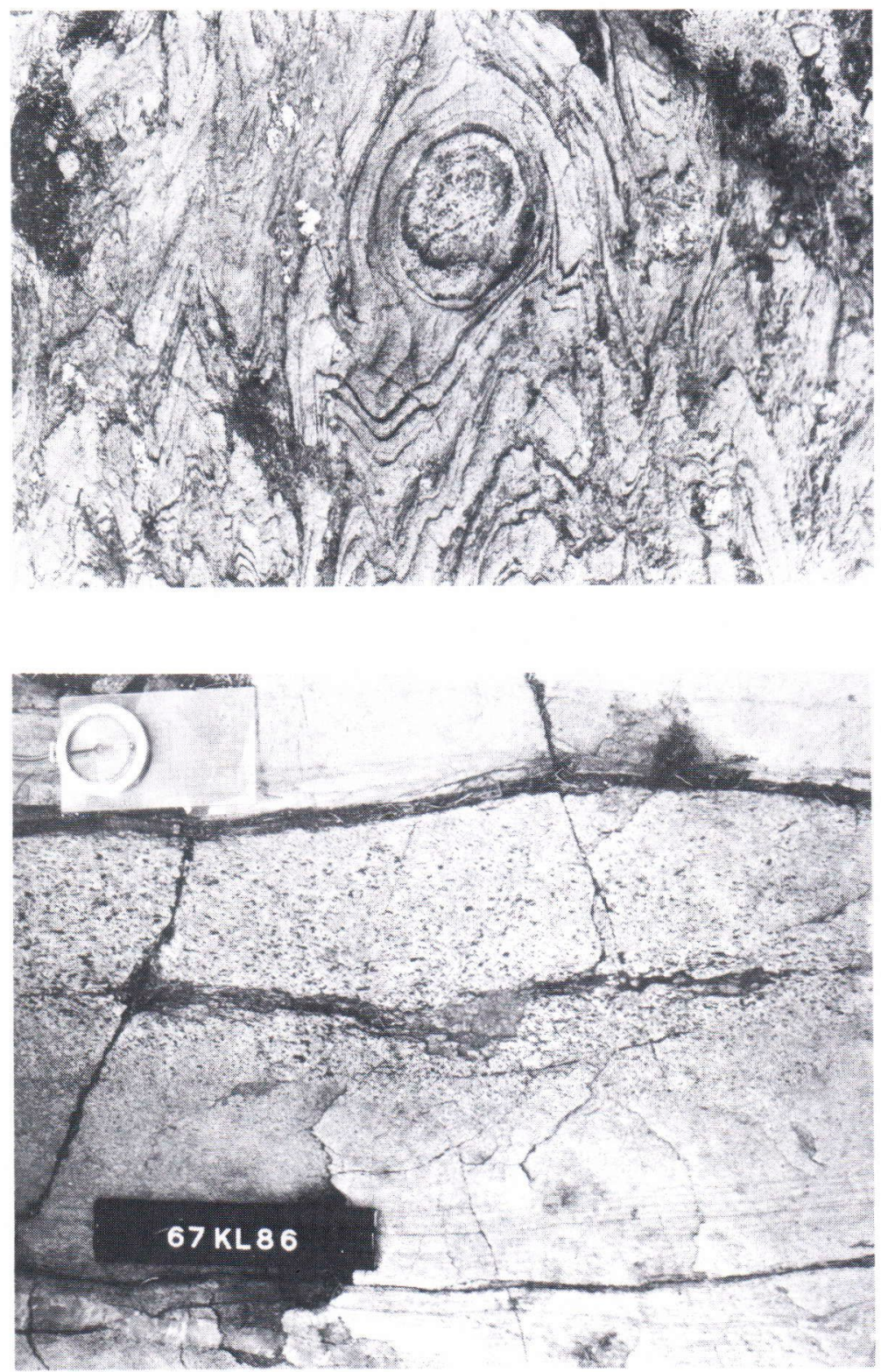

Fig. 14. Gneissic metaturbidite of the Mataramäki Gneiss at Tiukumäki. The sphere is a calcareous concretion $(\varnothing 10$ $\mathrm{cm})$.
Fig. 15. A $\mathrm{T}_{\mathrm{ab}}$ metaturbidite bed (above the compass) with pebbly major lower part and laminated upper part. Mataramäki Gneiss, Patvinperä. figs. 22-24). The more metamorphozed parts of the MmG consist of banded gneisses with alternating psammitic and pelitic bands.

The primary structures locally preserved prove that this lithodeme represents metaturbidites.

Correlation: The metapsammite occurrence of
Isomäki (north of Kukkomäki) is included, with certain reservations, into the MmG. The conglomeratic parts of the lithodeme in particular resemble the finer-grained conglomerates of the Haajainen Formation and the MmG is interpreted to represent the latter's more distal extension. 
The Näläntö-Piippola Belt (NPB) (Western lithodemic dericatives of the Rotimojoki Formation)

Introduction: Under this heading the schists, gneisses and migmatites which run from Sadinkangas in the south via Loutemäki, Hillokankaat and Kansanneva to Perämaankangas in the northwest (Fig. 3) and continue outside the study area to Piippola (Fig. 1) are described. The naming and grouping of these rocks in terms of stratigraphical nomenclature is problematical. Originally and (strato)stratigraphically they most probably represent the same sediment unit of which the Rotimojoki Formation is the least metamorphosed part (Fig. 16). Lithologically they differ, however, so much from the $\mathrm{RjF}$ that, if lithology is applied as the only classification criterion, they and the RjF should be treated, in the procedure recommended by ISSC (1987), as separate lithostratigraphic units. This shows that the stratigraphic classification proposals by NACSN (1983) and ISSC (1987) for metamorphic terrain may both cause some practical complications and shortcomings. Obviously the purpose of the stratigraphic classification has to be taken into consideration; if the emphasis is put on the original stratigraphic position and geometry, then the present secondary (metamorphic) lithology of metasedimentary rock bodies should be neglected as a classification criterion. On the oth- er hand, if the stratigraphic classification is also intended to serve metamorphic petrology the metamorphically different parts of an originally single stratigraphic unit should be separated (cf. Fig. 16). Because this paper is intended to serve both purposes an informal usage has been selected and the rocks in question are grouped under the class which indicates that they differ in secondary lithology from the $\mathrm{RjF}$ but correlate stratigraphically with it. They are called collectively the Näläntö-Piippola Belt (NPB) of which they form the bulk.

Outcrops and thickness: The NPB rocks are best exposed in the Sadinkangas $(\mathrm{x}=7073.0$, $\mathrm{y}=485.7)$, Loutemäki $(\mathrm{x}=7082.4, \mathrm{y}=474.7)$, Hillokankaat $(\mathrm{x}=7092.6, \mathrm{y}=466.1)$, Kansanneva $(\mathrm{x}=7113.6, \mathrm{y}=473.0)$ and Perämaankangas $(\mathrm{x}=7120.1, \mathrm{y}=466.0$ ) areas (Fig. 3). The Sadinkangas-Loutemäki-Hillokankaat occurrence forms a synform which flanks the Pirttimäki Complex or the Mataramäki Gneiss in the northeast and the Turhala Gneiss and Svecokarelidic granitoids in the west. The Kansanneva and Perämaankangas occurrences flank the $\mathrm{PpC}$ in the east but are intruded or migmatized by Svecokarelidic granitoids in the west (the Pyhäntä granite, the Lamujärvi Complex), south (Huhmarkangas granite) and north (the Kestilä granite). They are separated from each other by a major $\mathrm{D}_{4}$ fault. All the contact zones are un-

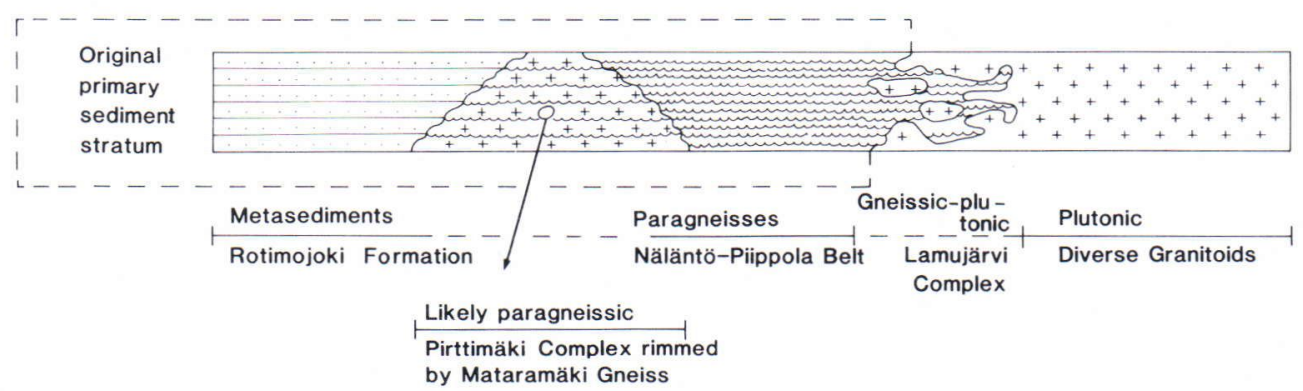

Fig. 16. A scheme showing the original stratostratigraphic relationship of the Näläntö-Piippola Belt with the Pirttimäki Complex and the Rotimojoki Formation. The latter was underlain by the Haajainen Formation (not shown). On the basis of their present secondary lithologies (symbolized by different horizontal ornaments) all these units form distinctive entinities of their own but originally they formed a single lithostratigraphic stratum of a group rank. 
exposed, but lithological observations indicate a metamorphic gradation between the NPB and the PmC at Pilpankangas.

The exact thickness of the metasedimentary pile cannot be estimated because of scattered nature of the outcrops, the complex structure and the metamorphism. However, the original sequence was at least many hundreds of metres thick.

Structure: The NPB forms a synformal $\mathrm{D}_{2}$ structure west of the Ahonkylä Antiform. This structure was deformed by $\mathrm{D}_{4}$ folding and faulting. The internal structures of each of the subareas are complex.

Lithology: The degree of metamorphism of the belt increases from Sadinkangas, where the rocks are amphibolite facies schists, to the northwest where they are gneisses and grade into the migmatites of the Lamujärvi Complex. The belt contains two major metasedimentary lithologies: 1) mica schists and mica gneisses and 2) metapsammites and psammitic gneisses. Mica schists occur at Sadinkangas where they show primary turbiditic features (Fig. 17) and so can be considered as finegrained metaturbidites. Mica schists without primary structures are common in other parts of the belt, especially in the eastern parts of Kansanneva and Perämaankangas, where they are often garnet-bearing. As the grade of metamorphism increases the mica schists grade into banded mica gneisses (Fig. 18). Metapsammites occur as intermembers within the more pelitic schists and gneisses. In less metamorphosed areas, in the south, they often show solitary or amalgamated massive or graded psammite beds which are clearly $\mathrm{T}_{\mathrm{a}}$ turbidites. The more gneissic types do not show primary structures but, on the basis of their overall massive, psammitic and blastoclastic nature, they are readily identified as more metamorphosed $\mathrm{T}_{\mathrm{a}}$ turbidites.

Electromagnetic maps indicate that the belt also contains a lot of black schists and related rocks. These are, however, exposed only in one outcrop south of Sadinkangas.

An areally restricted but lithologically signifi- cant rock association is encountered at Loutemäki, where amidst the gneisses metachert and silicate iron-formation units with psammitic $\mathrm{T}_{\mathrm{a}}$ metaturbidite interbeds outcrop. Savonlahti (1965) described these as quartzites and hornblende schists (see his figures 26 and 27).

In addition to metasedimantary rocks the belt contains amphibolite layers of which some show tuffitic lamination (Fig. 19) and is intruded and veined by Svecokarelidic intrusive rocks.

Correlation: The belt is correlated with the $\mathrm{RjF}$. Outside the study area in the south it joins the southern extension of the RjF at Kiuruvesi and Vieremä. In the northwest it may continue from Piippola to Pulkkila if not up to Paavola, but here the intense Svecokarelidic migmatization and anatexis make its mapping laborious (Fig. 1).

\section{Sadinkangas and Loutemäki gneisses}

At Sadinkangas $(\mathrm{x}=7073.0, \mathrm{y}=485.7)$ and Loutemäki $(\mathrm{x}=7092.5, \mathrm{y}=474.6)$, massive quartz-plagioclase gneiss bodies which were described in detail by Savolahti (1965, p. 45) occur. These rocks are problematical, because they are rather homogeneous, granoblastic and consist mainly of felsic minerals quartz, plagioclase and microcline with subordinate biotite. These occur closely associated with turbidites and could represent completely recrystallized psammitic turbidites of unusual thickness and homogenity. Another choice is that they were orthogneisses.

\section{Gneisses southwest of lake Näläntöjärvi}

The poorly exposed southwestern corner of the study area is underlain by banded gneisses in the Turhala-Remeskylä area and by gneisses and schists at Raippamäki and Lahnavuori. Their mutual relationships and relations to the Näläntö-Piippola Belt are not known.

\section{Turhala Gneiss (TuG)}

Definition: The gneisses between the NPB at 
Fig. 17. A gneissic mica schist with thin psammite interbeds at Sadinkangas. Näläntö-Piippola Belt.
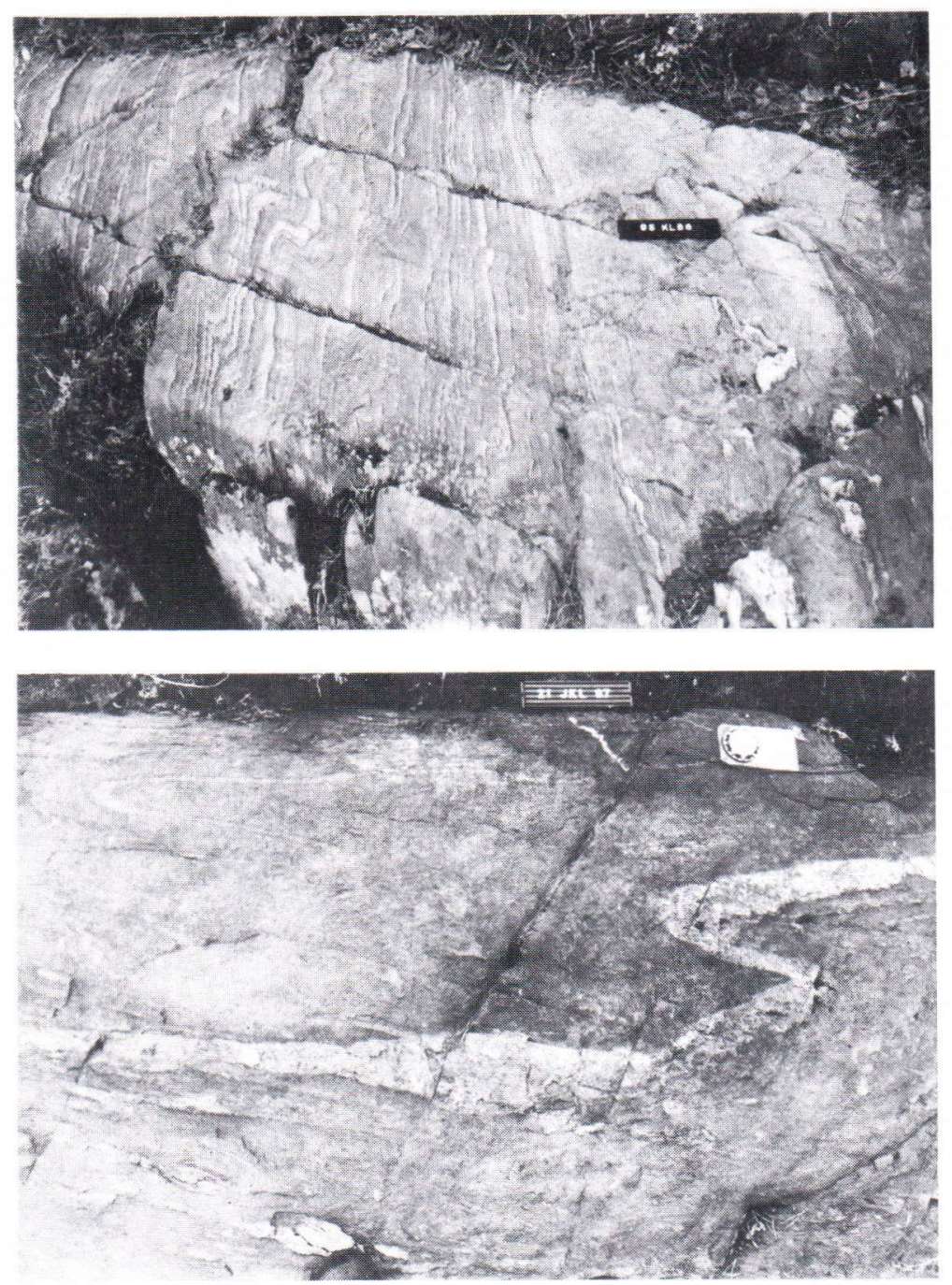

Fig. 18. A mica gneiss with poorly preserved psammite interbeds at Tyrsävä. Näläntö-Piippola Belt.

Sadinkangas and Hillokankaat and the Lahnavuori suite, southwest of Lake Näläntöjärvi, are grouped into the lithodeme called the Turhala Gneiss.

Name and outcrops: The gneiss takes its name from the locality $(\mathrm{x}=7072, \mathrm{y}=479)$ where it is best but rather poorly exposed. Its contact zones are unexposed.

Structure: The TuG may form an $\mathrm{F}_{2}$ antiform.

Lithology: At Turhala, the lithodeme consists of banded hornblende-biotite-plagioclase gneiss with alternating darker and lighter layers. The rock contains amphibolite layers or boudins of which some show tuffitic features, grey orthogneissic fragments and green calcareous epidoterich concretions. Where the grade of metamorphism is lower the rock has a paragneissic structure with thin psammitic and pelitic beds of probable turbiditic origin.

Correlation: The weak turbiditic features and concretions indicate that the lithodeme may be considered as a more metamorphosed part of the Näläntö-Piippola Belt. 


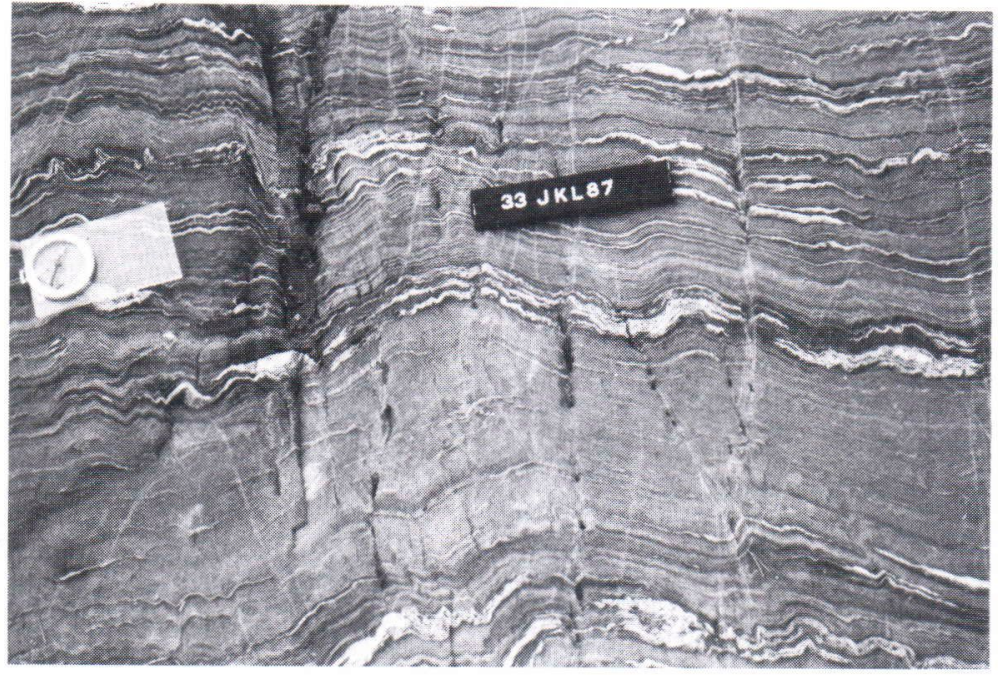

Fig. 19. Banded amphibolite with quartz veins. Näläntö-Piippola Belt. Sadinkangas.

\section{Lahnavuori suite (LvS)}

In the southwestern corner of the study area, at Lahnavuori, Liittovuori and Raippamäki, a variety of gneissic supracrustal rocks which differ markedly in lithology from the other gneisses and schists of the study area occur. These rocks contain e.g. »leptites» and so have a Svecofennian affinity. They are grouped into an informal unit called the Lahnavuori suite. They have not yet been studied in detail, but Wilkman (1931, p. 65) describes them briefly. The suite is separated from the Turhala Gneiss by a N-S-trending $\mathrm{D}_{3}$ fault and Svecokarelidic intrusive rocks.

\section{Lamujärvi Complex (LjC)}

Definition: The Svecokarelidic granitoids and relict mica gneisses in the surroundings of Lake Iso Lamujärvi and to the north of it form a granitoid-dominated complex called the Lamujärvi Complex.

Name and outcrops: The complex takes its name from Lake Iso Lamujärvi. It is poorly exposed and only a few solitary outcrops are encountered in its central part. Consequently its contacts are not visible.
Lithology: The metamorphic grade of the complex is markedly higher than that of the Kansanneva and Perämaankangas gneisses of the Näläntö-Piippola Belt and anatectic features are common in the supracrustal rock components. The complex consists of two major lithologies. 1) Svecokarelidic granites and granodiorites and 2) mica gneisses intruded and migmatized by the former. The mica gneisses still show locally some graded features but mostly they are banded gneisses or gneisses veined by thin granitoid layers. The granitoids are the dominant component and the mica gneisses can be considered as relics or inclusions within them.

Correlation: The supracrustal component represents relics of the NPB and the granitoids are Svecokarelidic.

\section{Early proterozoic intrusive rocks}

The gneisses and schists of the study area are abundantly intruded by early Proterozoic intrusive rocks; increasing in amount from the Iisalmi Complex towards the western and northern margins of the area. Because the main subject of this paper is the stratigraphy of the supracrustal rocks 
the main intrusive types encountered are only listed here.

\section{Metagabbro and gabbros}

Magnetite-bearing metagabbros correlative with the Otanmäki gabbros (Pääkkönen 1956, Talvitie and Paarma 1980, Kerkkonen 1979) occur at Vuolijoki. The gabbro west of Saaresjärvi may belong to this same group. A solitary body occurs at Kansanneva. Nowhere are the contacts of the gabbros with the supracrustal rocks exposed.

\section{Diorites and quartz diorites}

Small diorite bodies occur in the Sadinkangas-Loutemäki area and at Turhala. The Pirttimäki Complex is intruded by dioritic rocks at Viitamäki and in the Leppiperä-Juutinen area. The highly metamorphosed Rahajärvi gneiss, east of Saaresmäki, is also included in this group.

\section{Pegmatites, granites and granodiorites}

Granitoids occur frequently as smaller bodies, migmatizing layers, veins etc. among the gneiss complexes, gneisses and schists.

Of the larger granite bodies occuring in the western part of the area the most important are the granites of Kestilä (Wilkman 1931), Pyhäntä, Huhmarkangas, and those in the surroundings of Lake Näläntöjärvi (Savolahti 1965, p. 63).

\section{Diverse plutonic rocks}

The western margin of the study area belongs to an igneous suite consisting of granites, monzonites and diorites which intrude the Lahnavuori suite.

\section{Otanmäki alkali gneiss}

Northeast Itämäki, a distinctive pink gneiss with egirine and alkaliamphibole occurs. This rock is known as the Otanmäki alkali gneiss and is considered by Hytönen and Hautala (1985), and Puumalainen (1986) as a metasomatic unit replacing the Katajakangas formation and the Pirttimäki Complex, but it, or at least a part of it, may also be an alkaline granite (Marmo et al. 1966).

\section{Chronostratigraphy}

The only rock unit in the study area so far dated by radiometric methods is the Otanmäki alkali gneiss whose zircon gives an age of $2019 \mathrm{Ma}$ (Hytönen and Hautala 1985).

The Otanmäki metagabbro with which the metagabbros at Vuolijoki (Fig. 3) are correlated, have a zircon age of 2065 Ma (Talvitie and Paarma 1980). The Svecokarelidic plutonic rocks of the Kiuruvesi and Pihtipudas areas south of the study area gives ages of about 1900 Ma (Marttila 1976, 1981, Korsman et al. 1984). The cratonization age of the Iisalmi Complex is about 2600-2500 Ma (Simonen 1980a). On the basis of these data the depositional age of the supracrustal rocks falls between 2500-1900 Ma.

\section{Correlations}

In metamorphosed and deformed supracrustal areas like the Salahmi-Pyhäntä area stratigraphic correlations must be based on a proper understanding of the primary sedimentological and (strato)stratigraphic relations of the present metasedimentary units, the way in which metamorphism has changed the original lithologies and how the deformation reorganized the original sequences. The influence of igneous rocks piercing and melting the original sediments must also be taken into account. Isotopic studies are also important, but as to our area they are not yet carried out. In this chapter correlations within the study area are first made and then the correlation of the rock units with other 
metasedimentary units in central and northern Finland is discussed. In doing this attention is paid to the importance of structural geological studies in connection with lithostratigraphic and lithodemic working methods. The terms SumiSariola, Kainuu, Jatuli and Kaleva will be used to refer to the tectofacies defined by Laajoki (in press b).

\section{Intraregional correlations}

Figs. 20 and 21 (see also Fig. 16) give an interpretation of how the many diverse metamorphic rock units of the study area are correlated with each other. As the critical reader will have noticed the contact relationships of the different units are either unexposed, tectonized or intruded by the granitoids which, together with the variable grade of metamorphism and the variable intensity of deformation, hamper the correlation. However, applying the tectofacies concept (Laajoki in press b) the supracrustal rock units of diverse metamorphic build-up within the study area can be classified into three main classes: 1 ) The lower fluvial tectofacies, 2) the basinal (Kaleva?) tectofacies and its gneissic derivatives and 3) the rock units of unknown stratigraphic position (cf. Table 1).

The Lähdemäki and Potakka-aho formations are included in the first group. The second group includes the majority of the rock units: the Haajainen Formation, and the Mataramäki Gneiss, the former's likely western more metamorphosed equivalent, the Rotimojoki and Itämäki formations and their more metamorphosed equivalents within the Näläntö-Piippola Belt, the Ojanperä formation and the paragneissic component of the Lamujärvi Complex. The bulk of the Pirttimäki and Piiparinmäki complexes and the Turhala Gneiss, are considered as gneissic derivatives of the lower parts of this tectofacies exposed in antiform zones. The third group includes the Lautakangas and Katajakangas formations and the Lahnavuori suite which will be discussed in the next section.

\section{Interregional correlation}

There are five basic problems as to the correlation of the supracrustal rocks of the SalahmiNäläntö area with the early Proterozoic (Karelian) schists of nearby Kainuu, Kuopio, and Northern Pohjanmaa and the Svecofennian rocks to the southwest: 1) Correlation of the fluvial tectofacies. 2) Correlation of the Lautakangas formation. 3) Correlation of the less-gneissic part of the basinal tectofacies and the stratigraphic position of the Katajakangas Formation. 4) Correlation of the gneisses and amphibolites of the Pirttimäki and Piiparinmäki complexes and the Turhala Gneiss. 5) Correlation of the Lahnavuori suite and the overall stratigraphic relationship of the study area with the Svecofennides.

1) Korkiakoski and Laajoki (1988) discuss the correlation of the Lähdemäki Formation and conclude that it represents a relic of the Karelian platformal cover of the Archaean basement obviously correlative with the lowermost parts of the Kainuu Schist Belt and the Savo schists near Kuopio. The Lähdemäki and Potakka-aho formations also resemble the lower arkosic-conglomeratic part of the Northern Pohjanmaa schist area at Utajärvi (Honkamo 1985). On the basis of the underlying regolith (for details see Korkiakoski and Laajoki 1988) and the relatively great maturity of the metapsammites it seems that these rocks more likely belong to the Kainuu than the Sumi-Sariola tectofacies.

2) The Lautakangas formation is so poorly known that its correlation can only be outlined. Geophysical maps suggest that its occurrence was controlled by a narrow intracratonic basin bounded by SE-NE-trending faults. This kind of occurrence is typical of the volcanic rocks of the Sumi-Sariola tectofacies (Laajoki in press b) and so this formation is tentatively included in this tectofacies and consequently regarded as older than the Potakka-aho Formation.

3) The better preserved parts of the basinal facies (the Haajainen, Rotimojoki, Itämäki and Ojanperä formations, the Mataramäki Gneiss and the Näläntö-Piippola Belt) with their bulk 
SW

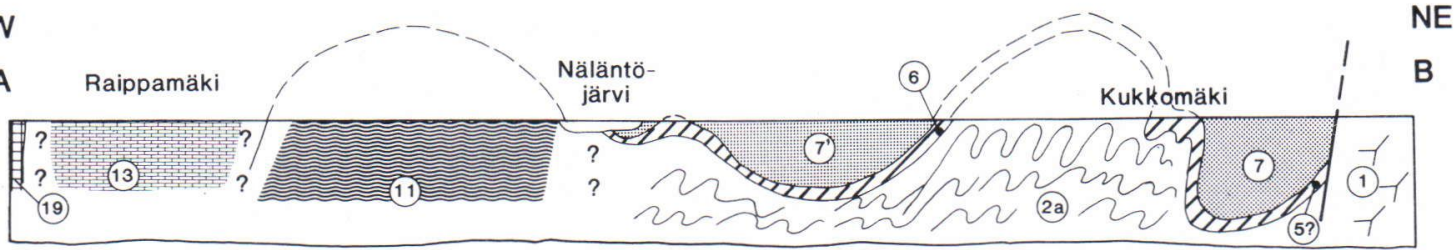

$10 \mathrm{~km}$

Fig. 20. A cross section from Raippamäki to Lähdemäki showing the stratigraphic relationships of the rock units. For symbols see Fig. 3.

flyschoidic lithologies bear great lithological similarities to the rocks of the Kaleva tectofacies. Recent studies (for reference and discussion see Laajoki, in press b) have shown that the internal stratigraphy of the Kaleva is much more complex than was formerly realized and that its reclassification into separate units is necessary. The overall similarity of the Kaleva of the Salah-
mi-Pyhäntä area with that of the Northern Pohjanmaa at Utajärvi and Kiiminki (Fig. 1) clearly points to the fact that these two schist areas were originally joined and that the Kaleva-type schists and gneisses of the Auho Fault Zone represent their transposed and more metamorphic derivatives (for more details see Korkiakoski and Laajoki 1988).

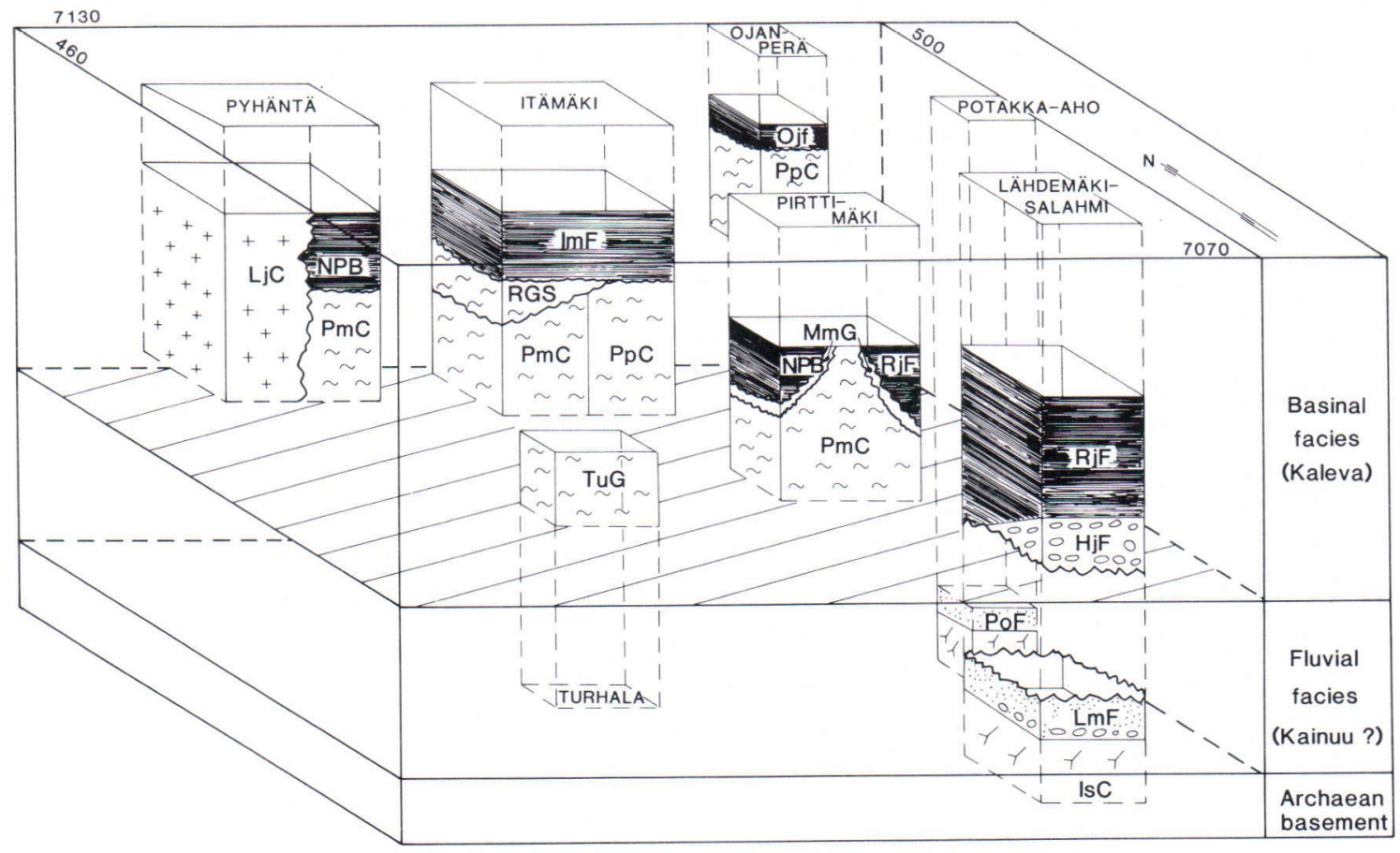

Fig. 21. Block diagram showing simplified stratigraphic columns from different subareas of the Salahmi-Pyhäntä area. Abbreviations: IsC = Iisalmi Complex. LmF = Lähdemäki Formation, $\mathrm{PoF}=$ Potakka-aho Formation, $\mathrm{HjF}=\mathrm{Haajai}-$ nen Formation, $\mathrm{RjF}=$ Rotimojoki Formation. $\mathrm{PmC}=$ Pirttimäki Complex, NPB $=$ Näläntö-Piippola Belt. MmG $=$ Mataramäki Gneiss. PpC $=$ Piiparinmäki Complex, Ojf $=$ Ojanperä formation. TuG $=$ Turhala Gneiss. RGS $=$ Rapisevankangas Gneiss Suite. ImF = Itämäki Formation. LjC = Lamujärvi Complex. 
The main problem, however, is how to connect the basinal facies with the Kainuu Schist Belt. The latter is a deformed schist basin bordered on its both margins by the Kainuu and Jatuli quartzites and cored by metaturbidites of the Kaleva. Its northwestern margin, however, differs from this general Karelian model in being a part of the Auho Fault Zone and containing the Central Puolanka Group. The latter, which is documented in detail (Laajoki 1986b, Laajoki and Korkiakoski 1988) bears lithological and stratigraphical similarities to the Lapponi (»pre-Jatuli») rocks of Lapland. The age determinations (see Laajoki 1986b) also support that the Central Puolanka Group predates the Jatuli and it may represent the deeper-water facies of the Kainuu (Laajoki, in press b). The Katajakangas formation is very similar to the psammitic turbidites of the Puolankajärvi Formation with which the Central Puolanka Group commences. According to Puumalainen (1986) a part of the Katajakangas formation was affected by the metasomatism which produced the Otanmäki alkali gneiss. If the zircon age of this gneiss defines also the age of this metasomatic event the Katajakangas Formation must pre-date $2019 \mathrm{Ma}$. This indicates that the Katajakangas metaturbidites are more likely correlative with the Kainuu than Kaleva tectofacies (Table 1).

The Kaleva of the eastern margin of the Kainuu Schist Belt has breccia-like conglomerates at its base which are overlain by turbidites, iron-formations and black schists which are in turn overlain by breccias and turbidites which grade to orthoquartzitic red bed-type psammites (Kontinen 1986, Gehör and Havola 1988, Laajoki 1988). The Kaleva of the Salahmi-Pyhäntä area deviates from this eastern Kaleva of the Kainuu and Höytiäinen (Ward 1987, 1988) basins and may represent a separate turbidite sequence called informally »the western Kaleva». This originally formed a SE-NW trending belt from Kuopio via Salahmi and Northern Pohjanmaa to Perä-Pohja and farther northwest to Sweden.
4) The interregional correlation of Pirttimäki and Piiparinmäki complexes and the Turhala Gneiss is questionable without isotopic data. Here, however, they are correlated with the Karelidic gneisses within the Auho Fault Zone north of Lake Oulujärvi (Fig. 1). The extent to which they include an Archaean component awaits isotopic studies of their coarse, massive gneissic parts. Similarly, whether or not some of them may be included in a younger age group of the Kettuperä (1930 Ma, Helovuori 1979) and Rastinpää (1930 Ma, Korsman et al. 1984) gneisses and the Laajamäki quartz diorite (1923 Ma, Vaasjoki and Sakko 1988) cannot be established without these studies.

5) With its leptitic rocks the Lahnavuori suite shows clear affinities with the rocks of the Pielavesi-Kiuruvesi-Pyhäsalmi belt (e.g. Marttila 1976; Helovuori 1979). The boundary between this belt and the Näläntö-Piippola Belt is, however, poorly exposed and the few outcrops are mostly of Svecokarelidic intrusive rocks. Thus, at this stage their mutual relationships cannot be established and, as Laajoki (e.g. 1984) has stressed, a study or the relationship between the Karelides and the Svecofennides forms one of the greatest challenges of the early Proterozoic geology of Finland.

\section{Conclusions}

The main conclusions concerning the early Proterozoic stratigraphy of the Salahmi-Pyhäntä area and its surroundings can be summarized as follows:

1. The Pirttimäki and Piiparinmäki complexes, earlier considered as Archaean, more likely consist mostly of early Proterozoic gneisses (originally distal Kaleva and older sediments) deformed multiply and metamorphosed by the Svecokarelidic orogeny.

2. The Archaean age of the gneisses west of the Kainuu Schist Belt in the surroundings of Oulujärvi and to the south and north of it 
should be re-evaluated in the light of conclusion 1 .

3. The Lautakangas formation may represent the products of the Sumi volcanism.

4. The Potakka-aho and Lähdemäki formations seem to represent relics of the Kainuu tectofacies.

5. The Haajainen Formation and the Mataramäki Gneiss are considered the proximal and distal parts, respectively, of a single coarse-clastic turbiditic unit with which the deposition of the western Kaleva began in its proximal parts.

6. The Rotimojoki, Itämäki and Ojanperä formations represent parts of the same group and the Näläntö-Piippola Belt forms their western lithodemic correlative. They are all correlated with the metaturbidites of the Northern Pohjanmaa Schist Belt, but their

\section{References}

Gaál, G. \& Gorbatschev, R., 1987. An outline of the Precambrian evolution of the Baltic Shield. Precambr. Res. 35, $15-52$.

Gehör, S. \& Havola, M., 1988. The depositional environment of the early Proterozoic Tuomivaara iron-formation and associated metasediments, eastern Finland. In Laajoki, K. and Paakkola, J. (eds.) Sedimentology of the Precambrian formations in eastern and northern Finland. Geol. Surv. Finiand, Spec. Paper 5, 109-134.

Hedberg, H. D. (ed.), 1976. International Stratigraphic Guide. A guide to stratigraphic classification, terminology, and procedure. International Subcommission on Stratigraphic Classification of IUGS Commission on Stratigraphy. Wiley and Sons, New York, 200 p.

Helovuori, O., 1979. Geology of the Pyhäsalmi ore deposit, Finland. Econ. Geol. 74, 1084-1101.

Honkamo, M., 1985. On the Proterozoic metasedimentary rocks in the northern Pohjanmaa Schist area, Finland. In Laajoki, K. and Paakkola, J. (eds.), Proterozoic Exogenic Processes and Related Metallogeny. Geol. Surv. Finland, Bull. 331, 117-130.

Hytönen, K. \& Hautala, T., 1985. Aegirine and riebeckite of the alkali gneiss of Pikkukallio in the HonkamäkiOtanmäki region, Finland. Bull. Geol. Soc. Finland 57, $169-180$ relationship with the Kainuu Schist Belt cannot be established on the basis of the data presently available.

7. The western margin of the Näläntö-Piippola Belt has been migmatized by Svecokarelidic granitoids which together with the lack of outcrops hamper the establishment of its relationship with the Svecofennian successions in the southwest.

Acknowledgements. This study is a contribution to the research projects $»$ Palaeosedimentology, structure and deformation of the Salahmi schists and Näläntö gneiss» and "Metamorphism and Deformation of the Crust» supported financially by the Academy of Finland. The manuscript was typed by Mrs. Raili Junnila and its English was checked by Mrs. Sheila Hicks, PhD. Mrs. Kristiina Karjalainen made the drafting. Constructive reviews of two anonymous referees greatly clarified the paper.

International Subcommission on Stratigraphic Classification, (Amos Salvador, Chairman) 1987. Stratigraphic classification and nomenclature of igneous and metamorphic rock bodies. Geol. Soc. Am., Bull. 99, 440-442.

Kerkkonen, O., 1979. Otanmäen titaanirautamalmin synty ja kehitys magneetti-ilmeniittiparin valossa. Unpubl. Manuscript, Univ. Oulu, Dept Geol., 89 p.

Kontinen, A., 1986. Early Proterozoic stratigraphy and sedimentation in the Hyrynsalmi area, eastern Finland. In Sokolov, V. A. and Heiskanen, K. I. (eds.) Early Proterozoic of the Baltic Shield. Proceedings of the FinnishSoviet Symposium held in Petrozavodsk 19th-27th August, 1985. Karelian Branch of the Academy of Sciences, USSR, Petrozavodsk, pp. 75-103.

Korkiakoski, E. \& Laajoki, K., 1988. The palaeosedimentology of the early Proterozoic Salahmi Schist Belt, Central Finland. In Laajoki, K. and Paakkola, J. (eds.) Sedimentology of the Precambrian formations in eastern and northern Finland. Geol. Surv. Finland, Spec. Paper 5, 49-73.

Korsman, K.; Hölttä, P.; Hautala, T. \& Wasenius, P., 1984. Metamorphism as an indicator of evolution and structure of the crust in Eastern Finland. Geol. Surv. Finland, Bull. 328, 40 p.

Laajoki, K., 1984. Puolangan kallioperägeologiset tutkimukset ja eräitä Suomen proterotsooiseen kallioperään liittyviä perusprobleemeja. Res Terrae 5, $31 \mathrm{p}$. 
-, 1986a. The Precambrian supracrustal rocks of Finland and their tectono-exogenic evolution. Precambr. Res. 33, $67-85$.

—, 1986b. The Central Puolanka Group - a Precambrian regressive metasedimentary sequence in northern Finland. Bull. Geol. Soc. Finland 58, 179-193.

—, 1988. The Pyssykulju Formation - a late Kalevian (early Proterozoic) orthoquartzite phase in Kainuu, northern Finland. In Laajoki, K. and Paakkola, J. (eds.) Sedimentology of the Precambrian formations in eastern and northern Finland. Geol. Surv. Finland, Spec. Paper $5,135-148$.

-, in press, $a$. Stratigraphic classification and nomenclature of igneous and metamorphic rock bodies. Discussion. Geol. Soc. Am., Bull.

- in press, $b$. Early Proterozoic tectofacies in eastern and northern Finland. In »Precambrian Continental Crust and Its Economic Resources». Developments in Precambrian Geology. Elsevier.

— \& Korkiakoski, E., 1988. The Precambrian turbidite tempestite transition as displayed by the amphibolite-facies Puolankajärvi Formation, Finland. Sediment. Geol. 58, 195-216.

—, Luukas, J. \& Tuisku, P., 1988. Salahmin, Nälännön ja Pyhännän liuskeiden ja gneissien stratigrafiset, metamorfiset ja rakenteelliset suhteet. Summary: Stratigraphic, metamorphic and structural relationships of the schists and gneisses of Salahmi, Näläntö and Pyhäntä. Geologi $40,59-69$.

Luukas, J., 1987. Kaakkois-Pyhännän kallioperä ja rakennegeologia. Res Terrae 11, 83 p.

Mäkinen, E., 1916. Öfversikt av de precambriska bildningarna i mellersta Österbotten i Finland. Summary: On the Pre-Cambrian geology of Central Österbotten in Finland. Bull. Comm. Géol. Finlande 47, 132 p.

Marmo, V.; Hoffren, V.; Hytönen, K.; Kallio, P.; Lindholm, O. \& Siivola, K., 1966. On the granites of Honkamäki and Otanmäki, Finland, with special reference to the mineralogy of accessories. Bull. Comm. Géol. Finlande $221,34 \mathrm{p}$.

Marttila, E., 1976. Evolution of the Precambrian volcanic complex in the Kiuruvesi area, Finland. Geol. Surv. Finland, Bull. 283, 109 p.

Marttila, E., 1981. Kiuruveden kartta-alueen kallioperä. Summary: Pre-Quaternary rocks of the Kiuruvesi map-sheet area. Suomen geologinen kartta 1: 100 000. Kalliperäkarttojen selitykset. Lehti 3323. Geol. Surv. Finland, 48 p.

North American Commission on Stratigraphic Nomenclature,
1983. North American stratigraphic code. AAPG Bull. $67,841-875$.

Pääkkönen, V., 1956. Otanmäki, the ilmenite-magnetite ore field in Finland. Bull. Comm. Géol. Finlande 171, 71 p.

Puumalainen, V. M., 1986. Otanmäen liuskealueen ja sen ympäristön kivilajit ja rakenne. Unpubl. M.Sc. thesis. Univ. Oulu, Dep. Geol., 53 p.

Savolahti, A., 1965. On the schists and associated intrusive rocks of the Vieremä-Kiuruvesi region. Bull. Comm. Geol. Finlande 218, 1-83.

Simonen, A., 1980a. The Precambrian in Finland. Geol. Surv. Finland, Bull. 304, 58 p.

Simonen, A., 1980b. Prequaternary rocks of Finland. Map 1: 1000 000. Geol. Surv. Finland.

Talvitie, J. \& Paarma, H., 1980. Precambrian basic magmatism and the TiFe ore formation in central and northern Finland. In Siivola, J. (ed.) Metallogeny of the Baltic Shield, proceedings of the symposium held in Helsinki, Finland, June 12-21, 1978. Geol. Surv. Finland, Bull. 307, 98-107.

Vaasjoki, M. \& Sakko, M., 1988. The evolution of the Raahe-Ladoga zone in Finland: isotopic constraints. In Korsman, K. (ed.) Tectono-metamorphic evolution of the Raahe-Lodoga zone. Geol. Surv. Finland, Bull. 343, 7-32.

Väyrynen, H., 1954. Suomen kallioperä. Otava, Helsinki, 260 p.

Ward, P., 1987. Early Proterozoic deposition and deformation at the Karelian craton margin in southeastern Finland. Precambrian Res. 35, 71-93.

-, 1988. Kalevian lithofacies and their relationships in the Hammaslahti-Rääkkylä district, North Karelia. In: Laajoki, K. and Paakkola, J. (eds.) Sedimentology of the Precambrian formations in eastern and northern Finland. Geol. Surv. Finland, Spec. Paper 5, 29-48.

Wilkman, W. W., 1924. Suomen geologinen yleiskartta. Kivilajikartta. General Geological Map of Finland. PreQuaternary rocks. Lehti-Sheet-(D4)-Nurmes 1: 400000. Geological Commission of Finland, Helsinki. (Now: Geological Survey of Finland, Espoo).

—, 1929. Suomen geologinen yleiskartta. Kivilajikartta. General Geological Map of Finland. Pre-Quaternary rocks. Lehti-Sheet-(C4)-Kajaani. 1: 400 0000. Geological Commission of Finland, Helsinki. (Now: Geological Survey of Finland, Espoo).

—, 1931. Suomen geologinen yleiskartta 1: 400 000, lehti C4, Kajaani. Kivilajikartan selitys. 274 p.

Received February 4, 1988

Revised and accepted August 5, 1988 